\title{
The Determinants of Environmental Migrants' Conflict Perception
}

\author{
Vally Koubi, Tobias Böhmelt, Gabriele Spilker, and Lena Schaffer
}

\begin{abstract}
Migration is likely to be a key factor linking climate change and conflict. However, our understanding of the factors behind and consequences of migration is surprisingly limited. We take this shortcoming as a motivation for our research and study the relationship between environmental migration and conflict at the micro level. In particular, we focus on environmental migrants' conflict perceptions to shed new theoretical and empirical light on this debate. We contend that variation in migrants' conflict perception can be explained by the type of environmental event people experienced in their former home, i.e., gradual, long-term or sudden onset, short-term environmental changes. We examine and further develop this argument before quantitatively analyzing newly collected micro-level data on intra-state migration from five developing countries. The results emphasize that migrants who suffered from gradual, long-term environmental events in their former homes are more likely to perceive conflict in their new location than those having experienced sudden, short-term environmental events. These findings are therefore in line with our theoretical argument that environmental migrants who suffer to a large degree from environmentally induced grievances, are ultimately more likely to perceive conflict and challenges in their new homes.
\end{abstract}

Keywords: conflict perceptions; environmental change; migration; gradual, long-term environmental events; sudden, short-term environmental events 


\section{Introduction}

Extreme weather events are frequently seen as important drivers of migration. For example, the Intergovernmental Panel on Climate Change ${ }^{1}$ contends that migration, i.e., the movement of people, is likely to be triggered by climate change in the form of stronger and more frequent storms and floods (sudden onset, short-term events) or droughts and rising sea levels (gradual, long-term events). ${ }^{2}$ Warraich, Zaidi, and Patel $^{3}$ report that several million people were internally displaced in the aftermath of the 2010 floods in Pakistan; and globally, it is estimated that an average of 22.5 million people have been displaced by climate-related disasters each year between 2008 and 2014. ${ }^{4}$ This number equals about 62,000 individuals a day - with almost all of these displacements occurring in developing countries with weak political institutions. ${ }^{5}$ Some studies even predict that climate change could force 200 million people moving permanently or temporarily in the future. ${ }^{6}$

The influx of environmentally induced migrants into new areas, combined with poor socioeconomic conditions and weak political institutions, could lead to higher pressures on resources in those receiving areas and, subsequently, induce conflict. ${ }^{7}$ In this article, we aim at shedding light on the conditions under which environmental change could influence conflict by

\footnotetext{
${ }^{1}$ IPCC 2014.

${ }^{2}$ See also Foresight Project 2011; Laczko and Aghazarm 2009.

${ }^{3}$ Warraich, Zaidi, and Patel 2011.

${ }^{4}$ Norwegian Refugee Council 2015.

5 According to Raleigh, Jordan, and Salehyan 2008, environmentally induced migration tends to be internal and temporary, although migration across national borders is also possible, albeit less prevalent (see also Hunter, Luna, and Norton 2015; Foresight Project 2011).

${ }^{6}$ Myers 2002. These estimates, however, are based on the number of people exposed to increasing climatic risks and not on the number of people expected to actually migrate; different levels of vulnerability to climatic change and possible adaptation strategies are also not taken into account for these numbers (Gemenne 2011; Foresight Project 2011). We refer the reader to Piguet 2010 on the methods assessing the weight of the environment in migration processes.

7 Theisen, Gleditsch, and Buhaug 2013; Bernauer, Böhmelt, and Koubi 2012; Salehyan 2008; Raleigh, Jordan, and Salehyan 2008; Gleditsch, Nordås, and Salehyan 2007; Reuveny 2007; Barnett and Adger 2007; Kahl 2006; HomerDixon 1999; Suhrke 1997. Additional mechanisms could pertain to ethnic tensions if the arrival of newcomers upsets an unstable ethnic balance; distrust between sending and receiving areas if the origin location perceives maltreatment of migrants; and fault lines that are rooted in pre-existing tensions following socioeconomic issues (Reuveny 2007; Goldstone 2001; 2002). Several scholars, however, argue that most of the mechanisms potentially turning migration into a cause of conflict in receiving areas are drawn from the refugees' role in the spread of civil war (Salehyan and Gleditsch 2006). Hence these mechanisms may then not be directly applicable in the case of environmental migration (see Gleditsch, Nordås, and Salehyan 2007; Raleigh, Jordan, and Salehyan 2008).
} 
examining the migration mechanism at the micro level. While some studies argue that individuals impoverished by environmental degradation "become desperate people, all too ready to challenge governments," 8 we contend that such claims might be too deterministic in that they almost imply that all types of environmental change lead to conflict and that all environmental migrants are equally prone to conflictive behavior. Against this background, we develop an argument and empirically test how exposure to different types of environmental events in the migrants' former locations shapes their conflict perception in their new place of residence.

Existing research on the environment-conflict nexus has not provided robust empirical evidence so far. ${ }^{9}$ One reason might be that most empirical studies, although often accounting for some contextual factors, model this relationship directly. ${ }^{10}$ Yet, while environmental/climatic conditions per se are unlikely to cause conflict, environmental change could act as a "threat multiplier" ${ }^{\prime 1}$ in that it has the potential to exacerbate a wide range of existing and often interacting conflict drivers, such as high population growth, resource scarcity, or poor governance. Recent studies thus began to analyze the relationship between climate/environmental change and conflict in a multi-stage framework in that conditional effects and indirect links from the environment and climate change to conflict, mostly via economic conditions, food insecurity, and production shocks, are now increasingly being considered. ${ }^{12}$ Most of this work finds support for such indirect links, but the migration channel ${ }^{13}$ through

\footnotetext{
${ }^{8}$ Myers 1993, 22

${ }^{9}$ Buhaug 2016; 2015; Salehyan 2014. However, Hsiang, Burke, and Miguel's (2013) meta-analysis of 60 studies reports "strong causal evidence" that climatic events are linked to social conflict at all scales and across all major regions of the world (see also Burke, Hsiang, and Miguel 2015a). Their meta-analysis, however, has been criticized with respect to sample selection, selection of indicators, and the interpretation of results (Buhaug et al. 2014).

${ }^{10}$ Fjelde and von Uexkull 2012; O'Loughlin et al. 2012; Hsiang, Meng, and Cane 2011; Theisen, Holtermann, and Buhaug 2011; Buhaug 2010; Burke et al. 2009.

${ }^{11}$ CAN 2007.

12 Von Uexkull et al. 2016; Caruso, Petrarca, and Ricciuti 2016; Schleussner et al. 2016; Buhaug et al. 2015; Gartzke and Böhmelt 2015; Smith 2014; Maystadt and Ecker 2014; Koubi et al. 2012.

${ }^{13}$ See, e.g., Burke, Hsiang, and Miguel 2015a; Kelley et al. 2015; Reuveny 2007. In general, (internal) migration of any cause is frequently seen as a driver of political violence. For instance, Fearon and Laitin 2011 argue that the civil war in Sri Lanka was prompted by Sinhalese migration into traditionally Tamil areas. Bove and Böhmelt 2016 examine the link between migration and terrorism.
} 
which changes in the environment could significantly increase the probability of conflict has rarely been explored, and existent empirical evidence remains ambiguous. ${ }^{14}$

The challenge to quantitatively study how environmentally induced migration affects conflict lies in isolating the effect of environmental change on migration. Existing research on the environment-conflict relationship mainly focuses on aggregated levels of analysis, e.g., the country or region level, but this risks drawing imprecise inferences due to the difficulties in separating the effect of environmental change from the many other determinants of conflict. In detail, the challenge is to show that it was indeed environmental change in the first place that led people to become migrants and, second, that conflict in the host region arose due to the influx of exactly these migrants. With this research, we seek to overcome this challenge by focusing on the individual, i.e., the micro level, and analyzing newly collected survey data on environmental changes, migration and conflict perceptions. We are thereby able to pinpoint whether migration decisions are motivated by environmental events and whether this, in turn, influences individuals' conflict perceptions.

There is substantial variation among environmental migrants in perceiving conflict in their new locations, and the question is whether different forms of environmental change contribute to this variation. ${ }^{15}$ We concentrate on two types of environmental change, i.e., gradual, long-term vs. sudden, short-term environmental events, and analyze how they affect migrants' perceptions of conflict. ${ }^{16}$ In doing so, we follow a recent trend in international relations ${ }^{17}$ that seeks to understand and evaluate the micro foundations of existing macro-level results. Focusing on the micro level allows us to carefully identify the different steps establishing the presumed causal

\footnotetext{
${ }^{14}$ Bernauer, Böhmelt, and Koubi 2012; Salehyan 2008.

${ }^{15}$ While we are aware that migrants are often seen as a threat to receiving societies and, hence, they are likely to encounter constant economic and social obstacles (Sedikides et al. 2009) that may exacerbate their conflict perceptions, we do not examine variation between migrants and the local population because of data limitations.

${ }^{16}$ To measure gradual, long-term vs. sudden, short-term environmental events we also rely on our survey data. In particular, we use a measure that captures whether respondents in our survey perceived environmental events to be present in their original location. See below for further details and an extensive discussion.

${ }^{17}$ For example, Hall 2016; Linke et al. 2015; Linke, Schutte, and Buhaug 2015; Blair et al. 2013; Oyefusi 2008; Schaffer and Spilker 2016.
} 
chain leading from environmental change to migration - and then to conflict. Moreover, since it is hardly possible to systematically analyze actual conflict behavior at the individual level, we concentrate on the stage preceding real conflict by studying the willingness requirement for overcoming the barriers of violent collective action, ${ }^{18}$ namely conflict perceptions of environmental migrants. ${ }^{19}$

In our survey, migrants could express their conflict perceptions with regard to different issue areas, such as economic hardship, political conflict, social challenges, and environmental stress. While some of these forms of conflict perceptions might not necessarily be directly related to real conflict (e.g., economic hardship), other types of conflict perceptions like perceived political conflict are closer to actual conflict behavior. ${ }^{20}$ Moreover, the literature emphasizes that perception is the first aspect of behavior, ${ }^{21}$ highlighting that there are strong links between conflict attitudes and actual conflict conduct. ${ }^{22}$ As a result, examining whether environmental events are associated with environmental migrants' grievances, which eventually induce a heightened perception of conflict, will allow us to gain valuable insights into whether any presumed link between environmental change and conflict behavior rests on a sound micro-level foundation.

Our argument is that direct exposure to environmental change in their former location shapes migrants' conflict perception in their new place of residence. By inflicting casualties and destruction, environmental events have the potential to induce widespread grievances that could render exposed individuals to contemplate violence in order to rectify the situation that gave rise to these grievances. However, while people might be aggrieved by the "absolute" destruction of their livelihood, we argue that they are more likely to be aggrieved by their negative assessment of their "relative" well-being over time. We thus differentiate the impact of different

\footnotetext{
${ }^{18}$ Gurr 1970; Sandler 1992.

${ }^{19}$ Rummel 1976, for example, identifies perception as the first aspect of behavior.

${ }^{20} \mathrm{We}$ describe the operationalization of this variable and the underlying survey question in the research design.

${ }^{21}$ Rummel 1976.

${ }^{22}$ Linke et al. 2015
} 
environmental events on individuals' conflict perceptions, in particular gradual, long-term vs. sudden, short-term environmental events.

Sudden, short-term environmental incidents should affect most individuals equally and people are exposed to these incidents only for a short period of time. Hence the likelihood to develop relative deprivation and grievances that will lead to an increased conflict perception is low. Short-term events thus lead to (absolute) grievances of the people affected and might even instill a sense of common fate and solidarity. ${ }^{23}$ In contrast, gradual, long-term environmental events, by fostering relative deprivations due to differences in adaptive capacities and a longer time period of exposure, should increase the likelihood of conflict perceptions. Here, individuals are exposed to small-scale adverse climatic conditions that make them steadily try to adapt their productive strategies (e.g. use drought resistant crops, invest in irrigation systems) until adaptation fails, and they then decide to migrate. Sustained exposure to climatic events and unsuccessful adaptation thus raises an individual's (relative) deprivation as well as her conflict perception. The rationale is that deep-seated feelings of anger and injustice continue to live in the minds of migrants for a long time. Recent research from psychology ${ }^{24}$ suggests that exposure to and especially the duration of traumatic events can influence social functioning and how individuals perceive mechanisms aiming at promoting justice and fairness.

We ultimately expect that migrants who were exposed to gradual, long-term environmental events are more likely to perceive conflict in their destination location than migrants who experienced sudden, short-term events. Figure 1 illustrates the theoretical contribution of this study. In the following, we develop this argument in detail.

\section{Figure 1 here}

\footnotetext{
${ }^{23}$ Drury et al. 2015.

${ }^{24}$ For example, Hecker et al. 2013; Canetti-Nisim et al. 2009; Hobfoll, Canetti-Nisim, and Johnson 2006; Vinck et al. 2007; Sullivan et al. 1981.
} 


\section{Conflict Perception and Its Determinants: Gradual, Long-Term vs. Sudden, Short-Term}

\section{Environmental Events}

Are individuals who migrated from their former homes due to adverse environmental conditions more likely to perceive conflicts at their new locations? In fact, although there is evidence that conflict refugees are more likely to have developed social norms in which violence is seen as a normal way to address problems, ${ }^{25}$ migrants originating from conflict-affected areas do not always harbor conflictive attitudes in their new location. ${ }^{26}$ Furthermore, studies in psychology show that migrants experience "acculturative stress" $" 27$ in reaction to socio-economic and cultural predicaments encountered in the new location and "these stressors can be exacerbated by conditions inherent in the immigrants' society of origin." ${ }^{28}$ In light of this research, we aim at shedding new theoretical and empirical light on the environment-migration-conflict nexus by focusing on migrants' conflict perceptions.

While our approach of focusing on conflict perceptions merely allows making indirect inferences about actual conflict behavior, it mirrors a more recent strand of the literature on individual-level conflict perceptions. By analyzing popular support for different militant groups in Afghanistan and Pakistan, Blair et al. ${ }^{29}$ and Lyall et al., ${ }^{30}$ for instance, claim that, and this is in line with our approach and contribution, without knowing how individuals in conflict settings perceive inflicted harms, we lack a key aspect of understanding the micro-level processes underlying these conflicts. Consequently, Lyall et al. ${ }^{31}$ suggest that "rather than relying solely on event data, we should integrate perceptions of harm and other individual level characteristics into our models if we are to understand how violence is understood by civilians and how it affects both attitudes and subsequent behavior." Furthermore, research shows that individuals who are

\footnotetext{
${ }^{25}$ Lischer 2008; Lyons 2007; Zolberg, Suhrke, and Aguayo 1989; see also Salehyan 2007.

${ }^{26}$ Hall 2016; see also Salehyan and Gleditsch 2006.

${ }^{27}$ Acculturative stress is defined as a migrant's "response [...] to life events that are rooted in intercultural contact" (Berry 2006, 43).

${ }^{28}$ Sedikides et al. 2009, 363

${ }^{29}$ Blair et al. 2013.

${ }^{30}$ Lyall et al. 2013

${ }^{31}$ Lyall et al. 2013, 697.
} 
dissatisfied with political and economic conditions are more susceptible to the manipulation by militant groups. ${ }^{32}$ Consequently, our research elaborates on one key component in the causal relationship between environmental change and conflict, and it rests on the assumption that without individuals perceiving environmentally induced migration as challenging enough to make them discontent with their current situation, environmental change is unlikely to play its envisaged role as a conflict promoter.

As indicated above, we focus on the indirect links between climate change and conflict via migration. Earlier work on this channel produced only mixed findings, however. For example, Reuveny $^{33}$ examines 38 cases of recognized environmental migration episodes, with about 50 percent of them having seen conflict occurring. He concludes that it is, however, difficult to identify "purely environmental” clashes. Raleigh, Jordan, and Salehyan ${ }^{34}$ also find little evidence that environmentally induced migration worsens already volatile situations in the developing world. Ghimire, Ferreira, and Dorfman ${ }^{35}$ report that displacement caused by catastrophic floods is likely to lengthen the duration of an existing civil conflict, but it does not affect the risk of new outbreaks. Moreover, Bohnet, Cottier, and $\mathrm{Hug}^{36}$ show that disaster-induced displacement does not significantly increase the risk of social unrest. However, for the period 2008-2011, they obtain some evidence that administrative units in the direct vicinity of a flood and displacement triggered by that event had a significantly higher probability of conflict. Finally, using irregular rainfall patterns in migrant-sending Indian states as an instrument for migration, Bhavnani and Lacina $^{37}$ demonstrate that greater rates of internal migration are associated with a higher risk of riots.

\footnotetext{
32 Stern 2010; Piazza 2007; Esposito, and Voll 1996.

${ }^{33}$ Reuveny 2007.

${ }^{34}$ Raleigh, Jordan, and Salehyan 2008.

${ }^{35}$ Ghimire, Ferreira, and Dorfman 2015.

${ }^{36}$ Bohnet, Cottier, and Hug 2014.

${ }^{37}$ Bhavnani and Lacina 2013.
} 
Against this background, the literature demonstrates that environmental change can lead to conditions of resource scarcity and, thus, as a stressor that potentially endangers individuals' well-being, decreases their personal income from production, or lowers their chances for future employment. ${ }^{38}$ Accordingly, it is likely that environmental change directly and negatively affects the perceptions of individuals regarding their satisfaction with and well-being at their present location. ${ }^{39}$ When the environmental stress becomes too severe, people might be increasingly discontent by the widening gap between their actual level of economic achievement and the level they feel they deserve and could have achieved under better climatic conditions. ${ }^{40}$ Moreover, some individuals are likely to be more dissatisfied, because elites could use their power to maintain their standards of living despite declining environmental conditions. These economic and political inequalities may incite relative deprivation and grievances that shape individuals' conflict perceptions. ${ }^{41}$

In his context, we contend that the impact on conflict perception depends on the type of environmental change, as distinct environmental events should affect individuals differently. To this end, our argument distinguishes between gradual, long-term and sudden onset, short-term environmental change. ${ }^{42}$ Gradual, long-term environmental events, such as droughts or desertification, have a rather small immediate impact on individuals. In addition, people may adjust their productive strategies over time when facing such problems. Responses include, among others, investments in irrigation systems, the use of drought-resistant plant and animal varieties, or the diversification of income sources. Despite the relatively small effects in the short-term and the plausible adaptation strategies, however, such events are in the longer term

\footnotetext{
${ }^{38}$ For example, Burke, Hsiang, and Miguel 2015b; Dell, Jones, and Olken 2014; Toll 2009.

${ }^{39}$ For example, Maddison and Rehdanz 2011; Luechinger and Raschky 2009; Ferrer-i-Carbonell and Gowdy 2007.

${ }^{40}$ Berkowitz 1989.

${ }^{41}$ Davies 1962; Gurr 1970; see also Cederman, Gleditsch, and Buhaug 2013; Cederman, Weidmann, and Gleditsch 2011.

${ }^{42}$ Koubi et al. 2016; Renaud et al. 2011.
} 
likely to disrupt economic growth, ${ }^{43}$ raise income inequality, ${ }^{44}$ and weaken state capacity. ${ }^{45}$ Furthermore, all these aspects of gradual, long-term events might particularly increase the willingness for violence ${ }^{46}$ and, hence, intensify conflict perceptions. ${ }^{47}$

Gradual, long-term environmental events are then likely to fuel personal grievances, since individuals' life satisfaction not only depends on perceived differences between what they possess and what they do not, but also on whether they observe progress in their own current or future status. ${ }^{48}$ Prediger, Vollan, and Herrmann ${ }^{49}$ demonstrate that sustained exposure to adverse climatic conditions might affect the likelihood of conflict behavior. They report results from a joy-of-destruction game in Namibia, where pastoralists, who were exposed to resource scarcity due to prolonged drought, were more likely to exhibit antisocial behavior - a higher willingness to reduce a fellow resource user's income at their own cost - relative to comparable neighboring pastoralists who had not suffered from similar sustained scarcity. Such particular experiences can have a lasting impact on individuals' cognitive, moral, and personality development as well as interpersonal relationships and coping abilities. ${ }^{50}$ Social learning theorists, moreover, emphasize that people become socialized to aggressive behavior and violence when they are constantly exposed to deprivation and grievances over a longer period of time. ${ }^{51}$ This is

\footnotetext{
${ }^{43}$ Burke, Hsiang, and Miguel 2015b; Dell, Jones, and Olken 2012; Barrios, Bertinelli, and Strobl 2010.

${ }^{44}$ Dennig et al. 2015; Reardon and Taylor 1996.

${ }^{45} \mathrm{Nel}$ and Righarts 2008; Biermann and Dingwerth 2004.

${ }^{46}$ Agnew 2012 not only points to higher temperatures and ensuing food shortages in raising crime levels, but also suggests that growing inequality and poverty triggered by climate induced economic volatility may contribute to an increase in violence.

${ }^{47}$ It is also worth noting that existing psychology research suggests that climate change may increase the likelihood of physical aggression and conflict due to the direct impact of rising temperatures (see, e.g., Anderson 2012; on the psychological impacts of climate change, see Doherty and Clayton 2011). In particular, experiments demonstrate that uncomfortably prolonged warm temperatures increase participants' feelings of anger, their perceptions of hostility in observed dyadic interactions, and their initial retaliatory aggressive behavior against a person whose prior harmful behavior was of an ambiguous nature (Anderson et al. 2000). In addition, Anderson and Delisi 2011 suggest that beyond the direct heat effects, growing malnutrition may prepare individuals for higher levels of aggression.

${ }^{48}$ Davies 1962; Gurr 1970.

${ }^{49}$ Prediger, Vollan, and Herrmann 2014.

${ }^{50}$ Taft, Creech, and Kachadourian 2012.

${ }^{51}$ Berkowitz 1993; Bandura 1973.
} 
especially the case when aggressive behavior is seen as appropriate as it might be the case in situations of resource scarcity. ${ }^{52}$

Consequently, by breeding relative deprivation, a gradual, long-term environmental event promotes grievances that could lead to the creation of individual conflict perceptions, which persist in individuals' minds for a long time. ${ }^{53}$ Sen exemplifies how retained grievances shape the way in which potential conflict might materialize: "[...] the nineteenth-century Irish Famine not only represented massive deprivation and hardship, but also led to deep-seated feelings of anger and disrespect that continue to live on in the minds of later generations that cannot have been directly affected." 54 Therefore, we expect environmental migrants having experienced gradual, long-term environmental events to be more likely to reveal conflict perceptions in their new location as they carry grievances to the new location.

Sudden, short-term environmental events such as storms and floods, conversely, despite the immediacy and the possible scale of their impact on the society in form of, e.g., a large number of casualties, considerable damage to agricultural crop, or the destruction of infrastructure, are unlikely to generate feelings of relative deprivation and widespread grievances that shape individual conflict perceptions. These events usually inflict hardship on all individuals irrespective of whether they earn their livelihoods from agriculture, manufacturing or services and, hence, are more likely to lead to absolute deprivation, which in turn leads people to rather blame fate than their own adaptive capacity vis-à-vis others in society.

Moreover, the equal exposure to a common fate at the group level might even lead to increased solidarity or pro-social behavior between victims of disasters as the literature on disasters in social psychology shows. ${ }^{55}$ Drury et al., for example, argue that the perception of a common fate induces a shared social identity, which in turn makes survivors of environmental

\footnotetext{
${ }^{52}$ See also Ember and Ember 1994.

${ }^{53}$ See also Catani et al. 2008.

${ }^{54}$ Sen 2011, 77.

${ }^{55}$ Drury et. al 2015; Drury, Cocking, and Reicher 2009; Jencson 2001; Rodriguez, Trainor, and Quarantelli 2006.
} 
disasters show solidarity rather than acting antisocial. ${ }^{56}$ While such solidarity may be confined to the immediate aftermaths of disasters, it should render the occurrence of relative grievances less likely.

Finally, despite the severity of their impact, short-term environmental events are typically only of a rather brief duration. Hence individuals' experience with any potentially aggressive behavior and violence should not be that strongly developed. Yet, a common argument in the literature is that there is an increased risk for future aggression when individuals become socialized for violence in conflictive environments. ${ }^{57}$ That said, affected individuals must be exposed to these negative environmental effects for a longer period of time. While this is the case for gradual, long-term environmental events, this is unlikely to be given for sudden, shortterm ones and hence migrants should be less likely to carry forward feelings of violence and aggression to their new location. To this end, we hypothesize that environmental migrants having experienced sudden, short-term environmental events are less likely to reveal conflict perceptions in their new location.

\section{Research Design}

\section{Survey Overview}

In order to systematically analyze the determinants of migrants' conflict perception, we rely on newly compiled data that allow for a quantitative analysis of individual-level conflict perceptions. In a first step, we focus on a data set comprising migrants only, i.e., people who decided to leave a specific area that experienced an environmental event and moved to another area within the same country. However, as migrants are unlikely to be a random sample and since those factors influencing conflict perceptions might also affect the initial decision to migrate, the Appendix discusses an analysis that focuses on both non-migrants and migrants who

\footnotetext{
${ }^{56}$ They provide empirical support for their theoretical argument by studying study the Chilean earthquake of 2010.

${ }^{57}$ Haer and Böhmelt 2016; Taft, Creech, and Kachadourian 2012; Holt, Buckley, and Whelan 2008; Garbarino 1995; Berkowitz 1993; Nordstrom 1992; Bandura 1973.
} 
originally come from the same area. When comparing individuals who have stayed in the area with those who have left, we are able to isolate the effect of environmental stressors on the decision to migrate as comparing individuals from the same region ensures that the context for all individuals is identical; at the same time, we can effectively control for selection effects. That said, the main results presented below and those obtained via the selection estimator do not differ in either substance or the direction of the effects.

Our data are based on individual, micro-level surveys in five countries: Vietnam, Cambodia, Uganda, Nicaragua, and Peru. The surveys were conducted between 2013 and 2014 and yielded 3,689 completed questionnaires in total of which about 50 percent $(N=1,854)$ stem from migrants. Note that the models discussed below are based on smaller samples due to missing values on some of the explanatory variables (discussed below). We focus on internal migration, since there is strong consensus in the literature that most migration flows associated with environmental factors are of an internal nature. ${ }^{58}$

The five case-study countries were chosen according to the following criteria. First, countries are regularly affected by weather-related events (storms, floods, droughts, etc.) and are vulnerable to climatic changes. ${ }^{59}$ Second, since our theory postulates different individual reactions to gradual, long-term vs. sudden, short-term environmental events, countries contain different regions experiencing these types of stressors in order to disentangle the effects of the two types of environmental events. And, third, countries come from different regions of the world (Southeast Asia, Sub-Saharan Africa, and Central and Latin America). ${ }^{60}$ Since existing research emphasizes that the environment-conflict relationship is rather context specific, our rationale for this last selection criterion was to study countries that widely differ in their political systems, their economic composition, and development, but are rather similar in their

\footnotetext{
${ }^{58}$ Hunter Luna, and Norton 2015, 3; Foresight Project 2011; Raleigh, Jordan, and Salehyan 2008.

${ }^{59}$ Kreft and Eckstein 2014; ND-GAIN 2013; EM-DAT/OFDA/CRED 2013; World Bank 2013.

${ }^{60}$ While we sought to cover different regions of the world that may be particularly vulnerable to climatic changes, the selected countries are not representative of a particular region or continent.
} 
vulnerability to climate change in that they experience both climate-induced gradual, long-term and sudden, short-term environmental events. While selecting such diverse countries might lower internal validity to some degree, our intention is to enhance external validity by showing that the same relationship between environmental change, migration, and conflict perceptions exists across a wider range of countries that do differ in key underlying political and socioeconomic conditions. Following these three criteria, the five countries we have chosen provide an ideal testing ground for our theory.

Based on information obtained from the EM-DAT/OFDA/CRED International Disaster Database $^{61}$ and archival research, we first identified relevant regions/provinces in each survey country that are mainly characterized by one particular environmental stressor that can be classified either as a gradual, long-term or a sudden, short-term environmental event. ${ }^{62}$ In turn, we randomly chose the departments/districts for the location of the survey. ${ }^{63}$ Finally, we randomly selected communes or villages in these departments or districts by using a grid system with random starting points in which the interviews of the non-migrants took place.

In contrast, a random sampling of migrants is hardly possible, since (by definition) they do no longer live in the same community as non-migrants. Furthermore, in the locations they have migrated to, we do not know ex-ante whether a specific person has migrated from relevant areas. Hence, we relied on a snowballing or chain-referral ${ }^{64}$ process to identify individuals who came from the same locations as the non-migrants, but who left their homes to live elsewhere, usually the regional or the national capital. Starting points for the snowballing were obtained by asking the non-migrant interviewees whether they knew of any individuals who had left their

\footnotetext{
${ }^{61}$ EM-DAT/OFDA/CRED 2013.

${ }^{62}$ Note that there would be no variation on the presence of environmental stressors, i.e., everyone experiences environmental stress, if we relied on a measure of objectively present environmental stress. Yet, we rather capture perceptions of environmental events and, in turn, conflict and thus there is variance and our research design is appropriate. We describe below how these perceptions pertaining to conflict (our dependent variable) and environmental events (our main explanatory variables) are operationalized.

${ }^{63}$ The appendix gives an overview of the locations of the surveys.

${ }^{64}$ This sampling method is frequently used in sociological studies of such hidden populations (see also Laczko and Aghazarm 2009; Warner 2011).
} 
community or district after having experienced the same environmental event(s), but did not belong to the same household. In total, and as indicated above, our sample comprises 1,854 migrants across the five countries, while a migrant is then also the unit of analysis. ${ }^{65}$

To illustrate this further, consider the following examples for each event in one of our sample countries. First, with respect to long-term events, individuals experienced droughts in Uganda in the Kotido and Moroto districts in the Karamoja region (Northeast Uganda) migrated to Mbale and Kampala. The migrants were then interviewed in Mbale and Kampala, while the relevant non-migrants were interviewed in the Karamoja region. Second, for an example of a sudden, short-term event, consider Vietnam: here, individuals experienced cyclones in the Giao Thuy district in the Red River Delta (North Vietnam) migrated to Hanoi, whereas individuals who suffered from floods in the Chau Phy district in the Mekong Delta (South Vietnam) move to Ho Chi Minh City. Thus, migrants were interviewed in Hanoi and Ho Chi Minh City about why they migrated and about their conflict perceptions, non-migrants accordingly in the areas of Giao Thuy or Chau Phy.

\section{Operationalization of Dependent Variables}

In order to capture conflict perceptions, we rely on five differently specified, yet interrelated dependent variables. All of these items are based on the survey and, hence, code migrants' perceptions. In detail, the first dependent variable captures conflict perception in the most general sense, as we analyze an item that captures whether respondents indicated they "faced any challenges in their current location" (1;0 otherwise). With this formulation, we not only capture individuals' conflict perception, but also conflict perception in the most broadest way as "challenges" could pertain to any conflict or tension (even low intensity ones) in the migrants'

\footnotetext{
${ }^{65}$ All interviews were personal interviews consisting of both closed and open-ended questions that lasted for about 30 minutes. We asked all individuals about their experience with the latest environmental event, certain personal information such as age, profession, or education as well as household specific questions. The full survey questionnaire is included in the appendix.
} 
new location. Out of 1,853 completed questionnaires for this conflict perception item, 921 (49.70 percent) individuals stated that they perceived some form of challenge in the place they moved to. Hence our sample is basically balanced for this first dependent variable. ${ }^{66}$

However, not all conflict perceptions are created equal and the first dependent variable may be too broad. To this end, we also asked respondents whether they could assign specific types of conflicts to the challenge identified. Table 1 specifies the sub-categories for these types of conflict perceptions. Using this information, we created four additional binary dependent variables, one for each sub-category of the general conflict-perception variable, and re-estimated the models. These types pertain to (1) social/psychological conflict perceptions $(N=663 / 1,853$; 35.78 percent), (2) economic conflict perceptions ( $N=747 / 1,853 ; 40.31$ percent $)$, environmental conflict perceptions $(N=302 / 1,853 ; 16.30$ percent), and (4) political conflict perceptions $(N=53 / 1,853 ; 2.86$ percent). With the approach of relying on various different conflict perception variables, we are not only able to ensure a maximum of generalizability for our findings, but also that we obtain an in-depth disaggregated perspective on the drivers of migrants' conflict perception.

Table 1 here

Note that the descriptive statistics (as displayed in the bottom rows of Table 1) suggest that some assumptions on the migration-conflict nexus are unlikely to hold. That is, earlier studies rely strongly on the claim that most migrants suffer from grievances and frustration regarding

\footnotetext{
${ }^{66}$ A possible objection to our approach might be that we cannot fully rule out an influence at the "new home" on conflict perceptions. That is, among others, Reuveny 2007, Shuval 2001, or Dancygier 2010 demonstrate that conflict is likely to emerge at receiving locations of migrants. For example, migrants' new environments could be less welcoming and people in receiving places may find some reasons for migration more legitimate than others (Sedikides et al. 2009; Berry 1997). That said, our distinction between migrants that lived in the new location for a fairly long time and those that only recently arrived allows us to safely assume that our results are due to what happened "at the source," i.e., migrants' previous place of residence. Specifically, migrants that only recently arrived at the destination location might have been less exposed to any conflict, stress, or challenges; conversely, migrants who spent a considerably longer time in the new location do have a higher chance of having been exposed to such conflict there. We return to this issue in the appendix.
} 
their situation, carry these perceptions and attitudes forward to the new location, which then increases the risk of conflict there. ${ }^{67}$ Our data highlight that not all migrants have conflict perceptions, but that there actually is a lot of variance on conflict perception both at the general and more disaggregated levels.

\section{Operationalization of Main Explanatory Items}

Our two main independent variables on environmental change pertain to sudden, short-term and gradual, long-term events, respectively. As in the case of the dependent variable, these items are not based on "objective" data, but interviewees' answers in the survey and, therefore, their perceptions regarding the type of the particular environmental event. ${ }^{68} \mathrm{We}$ do not use objective meteorological data because individuals tend to react to environmental changes based on their perception of it, rather than environmental change identified objectively with scientific data. ${ }^{69}$ Environmental perception encompasses direct experience of environmental events, yet, mediated by individuals' ability to cope with environmental change. ${ }^{70}$

For capturing these, we asked respondents to describe the main weather events they experienced over the past five years in their location/place of origin. Respondents could choose between several events such as heavy rain, storms and floods, or drought and salinity, but could also list any other weather occurrence that was not listed in the questionnaire, or were able to state that no incidents have occurred in the recent past. On the one hand, if individuals mentioned that they experienced any heavy rain, storm, flood, hail/snow, hurricane, cyclone, typhoon, and/or landslide/mudslide, we coded this event as a sudden, short-term environmental

\footnotetext{
${ }^{67}$ Lischer 2008; Lyons 2007.

${ }^{68}$ Moreover, recent research contrasts individual perceptions of environmental events with actual climatic events and finds that migrants and non-migrants indeed perceive climate change in different ways. In particular, while nonmigrants are slightly better in judging the actual extremeness of sudden, short-term events, migrants are slightly more accurate in assessing the actual extremeness of gradual, long-term events (Koubi, Stoll, and Spilker 2016). The appendix provides the survey questions, and also outlines what specifically refers to an environmental event and how this is measured. We return to this issue in the conclusion.

${ }^{69}$ Dessai et al. 2004.

${ }^{70}$ Black et al. 2013, 2011; Mortreux and Barnett 2009.
} 
event. According to our theoretical arguments, we expect that short-term environmental events do not have much of an impact on individuals' conflict perception. On the other hand, we coded salinity, drought, or desertification as gradual, long-term environmental events. Due to their long-term nature, we expect these to lead to more grievances and, thus, a higher likelihood of having perceptions of conflict.

\section{Operationalization of Control Variables}

Coming to our control variables, we build on earlier research on conflict, conflict perception, and individual-level migration. Most of our broad set of controls not only correlate with the conflict perception dependent variables and, thus, address the issue of omitted variable bias, but they may have also influenced an individual's decision to migrate in the first place. This latter aspect is particularly important for controlling for possible selection problems. The data for all of the control variables comes from our survey. First, there is a respondent's gender and age, as women as well as older individuals are less likely to migrate and may also have different conflict views than males or younger respondents. For example, age might be related to psychological phenomena, such as depression, under certain circumstances, although "most studies have shown that older adults differ little from younger adults in their approaches to coping with stress., 71 And Eisler, Skidmore, and Ward, ${ }^{72}$ among others, report that "stress appraisal is gender related," with men being more stress-prone than women.

Second, following recent explanatory models of migration networks emphasizing that migration decisions are made in a broader socio-economic context, ${ }^{73}$ we also incorporate a binary variable on whether another household member has migrated. Such networks increase the likelihood that relatives will follow once the first migrant has settled in her/his destination by

\footnotetext{
${ }^{71}$ Aldwin 1991, 174; see also Mirowsky and Ross 2003.

${ }^{72}$ Eisler, Skidmore, and Ward 1988.

${ }^{73}$ Hunter, Luna, and Norton 2015.
} 
sharply reducing the costs and risks associated with migration. ${ }^{74}$ This household-migration variable is also likely to affect conflict perceptions: if an individual moves to a place in which a household member already lives, the adaptation to the new environment might be less difficult and existing grievances could be less well pronounced. ${ }^{75}$

To control for potential economic influences, we rely on four different proxy variables from our survey, which we introduce into our models separately due to collinearity concerns. In general, the better the economic condition of an individual, the less likely she may perceive conflict in her new location. This corresponds to earlier research linking economic hardship with conflict and stress perceptions. ${ }^{76}$ In addition, an individual's economic condition could also have affected the initial decision to migrate. ${ }^{77}$ First, we consider a respondent's level of education as a proxy for economic opportunity via three dummy variables: whether a respondent has no formal education, whether a respondent received at maximum primary education, or whether a respondent received at maximum secondary education. Individuals with higher education levels serve as the baseline category.

Second, there is the interviewers' classification of the respondents' economic household status. As Hunter, Luna, and Norton emphasize "migration is often a household strategy to diversify risk."78 In particular, interviewers classified whether a household is economically below average, at average, or above average. We constructed two dummy variables - below and above average - based on this information, while those individuals with an average economic status constitute the reference category.

Third, there is the respondents' self-assessment as to whether economic reasons influenced their decision to migrate or not. In particular, all migrants were asked about their reasons to migrate and they could choose between, e.g., social, political, environmental, or economic

\footnotetext{
${ }^{74}$ Massey, Axinn, and Ghimire 2010; Massey 1990.

${ }^{75}$ Adger 2003; Kawachi and Berkman 2001.

${ }^{76}$ E.g., Mirowsky and Ross 2003; Armstrong and Schulman 1990.

${ }^{77}$ Lilleør and Van den Broeck 2011.

${ }^{78}$ Hunter, Luna, and Norton 2015, 1.
} 
reasons. For all respondents who stated that economic reasons contributed to their decision to migrate, we assigned the value of 1 to the variable Economic Reason ( 0 otherwise). While this self-assessment might be problematic as individuals could have the incentive to over- or underestimate certain factors due to personal reasons (e.g., migrants might not want to admit that they are not doing well economically), this variable controls for the potential self-selection (i.e., self-selection into migration) problem more accurately than the other items. In light of this rationale, individuals' self-selection into migration due to economic reasons might also affect whether they perceive conflict in their new location: people who go to a new location of residence "more voluntarily" to improve their economic situation tend to perceive less conflict than those who were forced to move to a new place due to changing environmental conditions.

The final variable as an alternative determinant of conflict perceptions and a control for the opportunity costs of migration captures a respondent's profession. This is a proxy for economic well-being and we include the following five professions in our models, while individuals working in the agriculture sector are the baseline: civil servants, individuals living from business sales, workers (industry, handicrafts, etc.), individuals with elementary professions such as day labor, and individuals living from remittances or other sources of income.

\section{Empirical Findings}

How do perceptions of sudden, short-term and gradual, long-term environmental events in their previous location affect migrants' perception of conflict in their new home? We have pooled the data across the five countries to examine the aggregated conflict-perception item, and we rely on a multi-level regression framework that allows us to control for influences beyond the micro level. Table 2 reports the results of the multi-level logistic regression models for the aggregated conflict-perception variable, i.e., the most general and broadly defined way to capture migrants' conflict perception. Models 1-4 are virtually identical as we consider in all these models our core 
variables of interest (Gradual, Long-Term Events and Sudden, Short-Term Events) as well as the standard individual-level demographics. However, we vary the set of variables on potential economic influences: Model 1 focuses on the education variables, Model 2 only considers the household-level income, Model 3 relies on whether a migrant moved due to economic reasons, and Model 4 focuses on the occupation of a respondent.

Table 2 here

Due to the structure of our data stemming from the hierarchical sampling procedure within countries, we use a random-intercept approach. As described above, we deliberately chose specific regions in each of the countries, because of the environmental problems they face, then relied on random sampling below this level, and used this information to identify the migrants in turn. Hence, we also have to control for certain regional factors located at either the macro or meso levels. Similarly, Hunter, Luna, and Norton point to influences coming from “a region's historical-political context." ${ }^{, 79}$ Hence, we incorporate a country-level as well as a regional-level intercept to account for the specific hierarchical, three-level nature of the pooled data set in each of the models in Table 2 and the models on the disaggregated conflict-perception variables (Tables 3-6). This accounts for unobserved heterogeneity at the regional and country levels. ${ }^{80}$ Both random intercepts are modeled according to a normal distribution. ${ }^{81}$

Two main results follow from Table 2. First, standard demographic variables have little impact on migrants' conflict perception. Only economic conditions do matter under some circumstances. Specifically, we find that women (Female) and younger individuals (Age) are more likely to perceive conflict in their new locations, but the relationship is not statistically

\footnotetext{
${ }^{79}$ Hunter, Luna, and Norton 2015, 5.

${ }^{80}$ Rabe-Hesketh and Skrondal 2009. Our results are robust across different specifications of the structure of the covariance matrix for the random effects, including when allowing all variances and covariances to be distinct.

${ }^{81}$ Gelman and Hill 2009.
} 
significant at conventional levels when looking at the models relying on the aggregate dependent variable. And while there is a conflict-perception lowering effect of networks, i.e., if a member of the household has already migrated, this is associated with lower conflict perception, this impact is also not statistically significant. For the economic conditions, it seems that neither the occupational status nor economic reasons to migrate in the first place seem to play a crucial role, yet, less educated migrants and those coming from a poor household are more likely to have overly conflictive perceptions. Thus there is some evidence that poverty leads to heightened conflict perceptions, which could then fuel actual conflictive behavior. This is in line with earlier studies at the individual or macro level. For example, $\mathrm{Urdal}^{82}$ argues that violence is strongly associated with an unequal access to employment or education. Situations of widespread, severe inequality then heighten the potential for alienated, frustrated, and excluded populations and, particularly, younger men to engage in violence. ${ }^{83}$ Brett and Specht ${ }^{84}$ also confirm this as they find strong micro-level support for the expectation that poverty, lack of schooling, and low alternative income opportunities are important reasons for conflict. Overall, however, these demographic variables

Second, we find support for our theoretical argument that it is particularly gradual, long-term environmental change that affects migrants' grievances, which then makes these individuals more likely to perceive conflict in their new location. This is supported by the positive and constantly significant coefficient estimate for Gradual, Long-Term Events in Table 2. In contrast, Sudden, Short-Term Events is associated with a positive coefficient estimate, but it is statistically insignificant throughout Models 1-4. As coefficients in non-linear setups like our hierarchical models for binary variables cannot be interpreted directly, we also calculated predicted probabilities for Conflict Perception=1 for Gradual, Long-Term Events, while holding all other variables constant at their means. Figure 1 displays these substantive effects for each

\footnotetext{
${ }^{82}$ Urdal 2006; Moser and Rodgers 2005.

${ }^{83}$ See also Goldstone 2001.

${ }^{84}$ Brett and Specht 2004; see also Collier 2000.
} 
model in Table 2 and also for the disaggregated conflict-perception items (Tables 3-6) we discuss below.

Figure 2 here

When examining Models 1-4 pertaining to Figure 1 (Gradual, Long-Term Events), we see that all scenarios independent of model specification are associated with positive probabilities of conflict perception. For example, the probability to perceive challenges in the new environment is on average nearly 60 percent when Gradual, Long-Term Events is set to 1 and all other variables held constant at their mean values. In other words, Gradual, Long-Term Events have, ceteris paribus, a strong and statistically significant effect on conflict perception.

Tables 3-6 here

Coming to the disaggregated versions of our dependent variable, Table 3 summarizes the findings when focusing on social/psychological conflict perceptions, Table 4 reports our results for economic conflict perceptions, Table 5 pertains to environmental challenges, and Table 6 relates to political conflict. Two findings appear particularly striking. On one hand, our core result of a positive and significant effect of Gradual, Long-Term Events holds across all models in Tables 3-6. Hence it is not a particular type of conflict perception that drives our estimations, but gradual, long-term environmental events at the original location/home of a migrant affect conflict perceptions generally. The substantive results for Gradual, Long-Term Events summarized in Figure 1 support this. For both economic challenges and social/psychological problems the probability to perceive challenges in the new environment lies at around 45 percent when Gradual, Long-Term Events is set to 1 and all other variables held constant at their mean 
values. The predicted probabilities we obtain are somewhat smaller in substance for political and environmental challenges, yet, positive and statistically different from 0 . The smaller effect size is likely to be driven by the fact that fewer people actually perceived conflict at a political $(N=53 / 1,853 ; 2.86$ percent $)$ or an environmental level $(N=302 / 1,853 ; 16.30$ percent $)$.

In the disaggregated conflict-perception estimations (Tables 3-6), some of the demographic controls now exert an impact that is statistically significant at conventional levels. For example, female migrants are much more likely than males to perceive social/psychological conflict (Table 3), but are statistically less likely than male migrants to perceive political conflict (Table 6). Second, the income-household effect we identified in Table 2 seems to be driven by those cases pertaining to social/psychological conflict. That is, conflict is much more likely to be perceived in poorer households; however, this effect largely disappears when looking at other types of conflict perception (although the effect for Poor Household persists in Models 10 and 14). Third, if someone migrated due to economic reasons, this person is also more likely to perceive economic conflict (Model 11). The variable Economic Reason is not associated with a statistically significant coefficient estimate in any other model. However, it may well be that endogeneity is responsible for this result: a migrant anticipates conflict at home, migrates due to this, and carries this attitude forward to the new location; she is then, not surprisingly, also more sensitive toward economic challenges.

In order to ensure the robustness of our results, we changed a variety of model specifications and re-run the estimations. In addition to incorporating other important drivers of conflict perceptions, such as a variable capturing political exclusion, we also show that our results are robust to controlling for selection into migration by employing a heckman-type probit selection model. All results can be found in the online Appendix. The Appendix also provides detailed maps of the survey locations as well as more details on the implementation of the survey, e.g. the questionnaire. 


\section{Conclusion}

Do environmental changes via their impact on migration increase the risk of conflict? While policymakers, the media, and public institutions tend to highlight this possibility, only few scientific studies offer a direct test of this relationship. Our research contributes toward filling this gap by studying individual migrants' conflict perceptions and by shedding light on the impact of environmental change on these perceptions. This approach allows us to better understand the causal mechanism that supposedly leads from environmental change via migration to conflict behavior.

We theoretically argued that individual-level conflict perceptions are conditional on the type of environmental event experienced by migrants. Sudden, short-term environmental incidents should affect most individuals equally and people are exposed to these environmental changes only for a short period of time. Hence the likelihood to develop relative deprivation and grievances that will lead to an increased conflict perception is low. In contrast, gradual, longterm environmental events, by fostering relative deprivations due to differences in adaptive capacities and a longer time period of exposure, should induce heightened grievances and migrants should be likely to perceive conflicts at their new locations.

Our empirical analysis relying on individual-level survey data from five developing countries strongly and robustly supports our argument. Whereas sudden, short-term environmental events do not significantly affect migrants' conflict perception, migrants who have experienced gradual, long-term environmental changes are significantly more likely to perceive conflict. These findings, while clearly highlighting the conflict potential of environmental migrants, suggest that previous treatments of environmental change, migration, and conflict may have been overly deterministic: not all migrants are always more "conflict-prone" under any circumstance. 
Against this background, one limitation of our approach is the reliance on pure perceptionbased measures in both assessing environmental events and conflict, which is rooted in our motivation to study the micro foundation of the climate change-migration-conflict nexus. Using either objective data on environmental change or on conflict would automatically imply a shift to a more aggregated level of analysis. Yet, with this kind of aggregation comes the challenge to show that environmental change indeed triggers individuals to become migrants in the first place, and that these kinds of migrants then might contribute to actual violence in their new host regions. One way for future research to overcome this challenge might be to rely on spatially disaggregated data. While such data exist for environmental change, we do not know of any such source for migration patterns. However, new data-compilation efforts, such as the use of remote sensing data to track the movement of migrants in regions with adverse environmental conditions, seems to us as one way forward.

In general, our results lead to important implications for existing theories of environmental conflict. While environmental migration does not necessarily lead to conflictive behavior under all circumstances, still there might be situations in which environmentally induced migrants can indeed be drivers of and behind conflict. This underscores the need to thoroughly examine the mechanisms that affect environmental migrants' conflict behavior. Priority should be placed on the development and testing of theories that account for plausible intervening and conditional factors, since the type of an environmental event and the nature of the local context in which it occurs as well as individual characteristics can exacerbate the challenges people face; and they can create new risks when people move.

It is, as a result, crucial to understand the exact causes of why migrants left their homes to be able to prevent potential conflict at new locations. Furthermore, it is equally important to examine the role played by perceptions. Incorporating and better understanding individual perceptions of climatic changes requires addressing the "why" behind these perceptions. Only 
then can we be able to comprehensively explain why people react to environmental changes the way they do and, thereby, are better positioned to study their conflict behavior. Finally, in order to achieve a robust, general understanding of the environmental migration-conflict nexus, we concur with Lyall, Blair, and Imai $^{85}$ that we should strive to connect individual conflict perceptions to actual conflict behavior and to group-level conflict by elevating individual conflict perceptions "from their current neglected status in our theories to the foreground of our study of civil war dynamics."

\footnotetext{
${ }^{85}$ Lyall, Blair, and Imai 2013, 697
} 
Table 1. Conflict Perception - Survey Questions Overview and Descriptive Statistics

\begin{tabular}{|c|c|c|c|c|c|c|}
\hline & $\begin{array}{c}\text { General Conflict } \\
\text { Perceptions }\end{array}$ & $\begin{array}{c}\text { Social/ } \\
\text { Psychological }\end{array}$ & Economic & Environmental & & Political \\
\hline Question Text & $\begin{array}{l}\text { Could you please } \\
\text { tell us if you are } \\
\text { facing any } \\
\text { challenges in our } \\
\text { current location? }\end{array}$ & \multicolumn{5}{|c|}{ Which types of problems are you currently facing? } \\
\hline $\begin{array}{l}\text { Response } \\
\text { categories }\end{array}$ & $\begin{array}{ll}> & \text { Yes } \\
> & \text { No } \\
> & \text { Don't know }\end{array}$ & $\begin{array}{l} \\
>\end{array} \begin{array}{l}\text { Discrimination } \\
\text { in new } \\
\text { community } \\
\text { Loneliness/ } \\
\text { isolation/ lack } \\
\text { of social } \\
\text { support } \\
\text { It is not as easy } \\
\text { as I thought it } \\
\text { would be here } \\
>\quad \begin{array}{l}\text { Inadequate } \\
\text { schooling for } \\
\text { children }\end{array} \\
\text { There is } \\
\text { insecurity } \\
\text { (physical, } \\
\text { sexual) } \\
\text { There is } \\
\text { exploitation } \\
\text { (physical, } \\
\text { sexual) } \\
\text { Other }\end{array}$ & $\begin{array}{ll} & \begin{array}{l}\text { Not enough } \\
\text { income from } \\
\text { livelihood } \\
\text { sources }\end{array} \\
\text { Unemployment } \\
>\quad \begin{array}{l}\text { Inadequate/ } \\
\text { unstable } \\
\text { housing } \\
\text { situation }\end{array} \\
>\quad \text { Homeless } \\
\text { No access to } \\
\text { health care } \\
\text { Not enough } \\
\text { money to } \\
\text { purchase food } \\
\text { Other }\end{array}$ & $\begin{array}{l}>\quad \begin{array}{l}\text { Poor sanitary } \\
\text { conditions }\end{array} \\
\text { No regular } \\
>\quad \text { access to water } \\
\text { Exposed to } \\
\text { regular } \\
\text { flooding or } \\
\text { other hazard } \\
>\quad \text { Other }\end{array}$ & $>$ & $\begin{array}{l}\text { There is } \\
\text { conflict within } \\
\text { my community } \\
\text { There is } \\
\text { conflict outside } \\
\text { my community } \\
\text { that is affecting } \\
\text { me } \\
\text { I cannot access } \\
\text { government } \\
\text { services } \\
\text { Other }\end{array}$ \\
\hline Migrants & 921 & 663 & 747 & 302 & & 53 \\
\hline Non-Migrants & 932 & 1190 & 1106 & 1551 & & 1800 \\
\hline
\end{tabular}


Table 2. General Conflict Perception Multilevel Logistic Regression Models

\begin{tabular}{|c|c|c|c|c|}
\hline & $\begin{array}{c}\text { Model } 1 \\
\text { (Conflict } \\
\text { Perception) }\end{array}$ & $\begin{array}{c}\text { Model } 2 \\
\text { (Conflict } \\
\text { Perception) }\end{array}$ & $\begin{array}{c}\text { Model } 3 \\
\text { (Conflict } \\
\text { Perception) }\end{array}$ & $\begin{array}{c}\text { Model } 4 \\
\text { (Conflict } \\
\text { Perception) }\end{array}$ \\
\hline Sudden, Short-Term Events & $\begin{array}{c}0.119 \\
(0.161)\end{array}$ & $\begin{array}{c}0.061 \\
(0.173)\end{array}$ & $\begin{array}{c}0.120 \\
(0.160)\end{array}$ & $\begin{array}{c}0.087 \\
(0.162)\end{array}$ \\
\hline Gradual, Long-Term Events & $\begin{array}{c}0.496 \\
(0.138)^{* * *}\end{array}$ & $\begin{array}{c}0.397 \\
(0.154)^{* *}\end{array}$ & $\begin{array}{c}0.499 \\
(0.138)^{* * *}\end{array}$ & $\begin{array}{c}0.504 \\
(0.139)^{* * *}\end{array}$ \\
\hline Female & $\begin{array}{c}0.093 \\
(0.111)\end{array}$ & $\begin{array}{c}0.114 \\
(0.135)\end{array}$ & $\begin{array}{c}0.089 \\
(0.110)\end{array}$ & $\begin{array}{c}0.093 \\
(0.111)\end{array}$ \\
\hline Age & $\begin{array}{l}-0.003 \\
(0.006)\end{array}$ & $\begin{array}{l}-0.005 \\
(0.007)\end{array}$ & $\begin{array}{l}-0.008 \\
(0.006)\end{array}$ & $\begin{array}{l}-0.009 \\
(0.006)\end{array}$ \\
\hline Household Member Migrated & $\begin{array}{l}-0.147 \\
(0.110)\end{array}$ & $\begin{array}{l}-0.037 \\
(0.133)\end{array}$ & $\begin{array}{l}-0.129 \\
(0.110)\end{array}$ & $\begin{array}{l}-0.132 \\
(0.111)\end{array}$ \\
\hline No Education & $\begin{array}{l}-0.164 \\
(0.292)\end{array}$ & & & \\
\hline Primary Education & $\begin{array}{l}-0.266 \\
(0.199)\end{array}$ & & & \\
\hline Secondary Education & $\begin{array}{c}-0.263 \\
(0.130)^{* *}\end{array}$ & & & \\
\hline Poor Household & & $\begin{array}{c}0.564 \\
(0.180)^{* * *}\end{array}$ & & \\
\hline Rich Household & & $\begin{array}{l}-0.189 \\
(0.213)\end{array}$ & & \\
\hline Economic Reason & & & $\begin{array}{l}0.031 \\
(0.139)\end{array}$ & \\
\hline Civil Servant & & & & $\begin{array}{l}-0.094 \\
(0.233)\end{array}$ \\
\hline Business Sales & & & & $\begin{array}{l}-0.041 \\
(0.150)\end{array}$ \\
\hline Craft and Trade Workers & & & & $\begin{array}{l}-0.182 \\
(0.227)\end{array}$ \\
\hline Elementary Occupation & & & & $\begin{array}{c}0.169 \\
(0.185)\end{array}$ \\
\hline Other Sources of Income & & & & $\begin{array}{l}-0.199 \\
(0.355)\end{array}$ \\
\hline Constant & $\begin{array}{c}0.082 \\
(0.473)\end{array}$ & $\begin{array}{l}-0.241 \\
(0.501)\end{array}$ & $\begin{array}{c}0.014 \\
(0.475)\end{array}$ & $\begin{array}{c}0.103 \\
(0.478)\end{array}$ \\
\hline Country Variance & $\begin{array}{c}0.775 \\
(0.559)\end{array}$ & $\begin{array}{c}0.804 \\
(0.557)\end{array}$ & $\begin{array}{c}0.760 \\
(0.535)\end{array}$ & $\begin{array}{c}0.776 \\
(0.549)\end{array}$ \\
\hline District Variance & $\begin{array}{c}0.189 \\
(0.084)\end{array}$ & $\begin{array}{c}0.149 \\
(0.086)\end{array}$ & $\begin{array}{c}0.189 \\
(0.083)\end{array}$ & $\begin{array}{c}0.194 \\
(0.085)\end{array}$ \\
\hline Observations & 1,804 & 1,316 & 1,812 & 1,781 \\
\hline Number of Groups & 5 & 5 & 5 & 5 \\
\hline Log Likelihood & $-1,069.549$ & -762.881 & $-1,076.723$ & $-1,061.441$ \\
\hline Wald $\chi^{2}$ & $20.40 * * *$ & $20.00 * * *$ & $16.40 * *$ & $19.54 * *$ \\
\hline
\end{tabular}

Table entries are coefficients from multilevel logistic regression models with country level and district level random effects; standard errors in parentheses.

*** significant at $1 \% ; * *$ significant at $5 \% ; *$ significant at $10 \%$. 
Table 3. Social/Psychological Conflict Multilevel Logistic Regression Models

\begin{tabular}{|c|c|c|c|c|}
\hline & $\begin{array}{c}\text { Model } 5 \\
\text { (Social/Psycholog.) }\end{array}$ & $\begin{array}{c}\text { Model } 6 \\
\text { (Social/Psycholog.) }\end{array}$ & $\begin{array}{c}\text { Model } 7 \\
\text { (Social/Psycholog.) }\end{array}$ & $\begin{array}{c}\text { Model } 8 \\
\text { (Social/Psycholog.) }\end{array}$ \\
\hline \multirow[t]{2}{*}{ Sudden, Short-Term Events } & 0.130 & 0.161 & 0.106 & 0.046 \\
\hline & $(0.169)$ & $(0.184)$ & $(0.168)$ & $(0.171)$ \\
\hline \multirow[t]{2}{*}{ Gradual, Long-Term Events } & 0.664 & 0.578 & 0.666 & 0.640 \\
\hline & $(0.147)^{* * *}$ & $(0.177)^{* * *}$ & $(0.146)^{* * *}$ & $(0.149)^{* * *}$ \\
\hline \multirow[t]{2}{*}{ Female } & 0.230 & 0.303 & 0.233 & 0.232 \\
\hline & $(0.117)^{* *}$ & $(0.141)^{* *}$ & $(0.115)^{* *}$ & $(0.117)^{* *}$ \\
\hline \multirow[t]{2}{*}{ Age } & -0.008 & -0.008 & -0.009 & -0.008 \\
\hline & $(0.007)$ & $(0.007)$ & $(0.006)$ & $(0.006)$ \\
\hline \multirow[t]{2}{*}{ Household Member Migrated } & -0.228 & -0.152 & -0.200 & -0.167 \\
\hline & $(0.116)^{*}$ & $(0.139)$ & $(0.115)^{*}$ & $(0.117)$ \\
\hline \multirow[t]{2}{*}{ No Education } & 0.132 & & & \\
\hline & $(0.277)$ & & & \\
\hline \multirow[t]{2}{*}{ Primary Education } & -0.124 & & & \\
\hline & $(0.219)$ & & & \\
\hline \multirow[t]{2}{*}{ Secondary Education } & -0.206 & & & \\
\hline & $(0.142)$ & & & \\
\hline \multirow[t]{2}{*}{ Poor Household } & & 0.593 & & \\
\hline & & $(0.188)^{* * *}$ & & \\
\hline \multirow[t]{2}{*}{ Rich Household } & & -0.536 & & \\
\hline & & $(0.222)^{* *}$ & & \\
\hline \multirow[t]{2}{*}{ Economic Reason } & & & -0.015 & \\
\hline & & & $(0.149)$ & \\
\hline \multirow[t]{2}{*}{ Civil Servant } & & & & 0.220 \\
\hline & & & & $(0.250)$ \\
\hline \multirow[t]{2}{*}{ Business Sales } & & & & 0.030 \\
\hline & & & & $(0.154)$ \\
\hline \multirow[t]{2}{*}{ Craft and Trade Workers } & & & & -0.186 \\
\hline & & & & $(0.256)$ \\
\hline \multirow[t]{2}{*}{ Elementary Occupation } & & & & -0.112 \\
\hline & & & & $(0.208)$ \\
\hline \multirow[t]{2}{*}{ Other Sources of Income } & & & & -0.489 \\
\hline & & & & $(0.479)$ \\
\hline \multirow[t]{2}{*}{ Constant } & -0.822 & -1.133 & -0.857 & -0.786 \\
\hline & $(0.450)^{*}$ & $(0.541)^{* *}$ & $(0.468)^{*}$ & $(0.480)^{*}$ \\
\hline \multirow[t]{2}{*}{ Country Variance } & 0.619 & 0.914 & 0.683 & 0.735 \\
\hline & $(0.456)$ & $(0.649)$ & $(0.490)$ & $(0.524)$ \\
\hline \multirow[t]{2}{*}{ District Variance } & 0.194 & 0.250 & 0.188 & 0.193 \\
\hline & $(0.098)$ & $(0.148)$ & $(0.094)$ & $(0.096)$ \\
\hline Observations & 1,804 & 1,316 & 1,812 & 1,781 \\
\hline Number of Groups & 5 & 5 & 5 & 5 \\
\hline Log Likelihood & $-1,000.376$ & -719.850 & $-1,009.657$ & -983.084 \\
\hline Wald $\chi^{2}$ & $32.40 * * *$ & $37.18 * * *$ & $28.71 * * *$ & $28.54 * * *$ \\
\hline
\end{tabular}

Table entries are coefficients from multilevel logistic regression models with country level and district level random effects; standard errors in parentheses.

*** significant at $1 \%$;* significant at $5 \%$; significant at $10 \%$. 
Table 4. Economic Conflict Multilevel Logistic Regression Models

\begin{tabular}{|c|c|c|c|c|}
\hline & $\begin{array}{c}\text { Model } 9 \\
\text { (Economic: }\end{array}$ & $\begin{array}{c}\text { Model 10 } \\
\text { (Economic) }\end{array}$ & $\begin{array}{c}\text { Model } 11 \\
\text { (Economic) }\end{array}$ & $\begin{array}{c}\text { Model } 12 \\
(\text { Economic) }\end{array}$ \\
\hline \multirow[t]{2}{*}{ Sudden, Short-Term Events } & 0.033 & -0.101 & 0.045 & 0.013 \\
\hline & $(0.167)$ & $(0.175)$ & $(0.166)$ & $(0.169)$ \\
\hline \multirow[t]{2}{*}{ Gradual, Long-Term Events } & 0.482 & 0.386 & 0.476 & 0.491 \\
\hline & $(0.143)^{* * *}$ & $(0.163)^{* *}$ & $(0.142)^{* * *}$ & $(0.144)^{* * *}$ \\
\hline \multirow[t]{2}{*}{ Female } & 0.047 & 0.075 & 0.074 & 0.057 \\
\hline & $(0.116)$ & $(0.137)$ & $(0.115)$ & $(0.116)$ \\
\hline \multirow[t]{2}{*}{ Age } & -0.003 & -0.002 & -0.003 & -0.004 \\
\hline & $(0.007)$ & $(0.007)$ & $(0.006)$ & $(0.006)$ \\
\hline \multirow[t]{2}{*}{ Household Member Migrated } & -0.157 & -0.049 & -0.150 & -0.132 \\
\hline & $(0.115)$ & $(0.135)$ & $(0.115)$ & $(0.116)$ \\
\hline \multirow[t]{2}{*}{ No Education } & 0.252 & & & \\
\hline & $(0.285)$ & & & \\
\hline \multirow[t]{2}{*}{ Primary Education } & 0.225 & & & \\
\hline & $(0.206)$ & & & \\
\hline \multirow[t]{2}{*}{ Secondary Education } & -0.182 & & & \\
\hline & $(0.139)$ & & & \\
\hline \multirow[t]{2}{*}{ Poor Household } & & 0.420 & & \\
\hline & & $(0.177)^{* *}$ & & \\
\hline \multirow[t]{2}{*}{ Rich Household } & & -0.018 & & \\
\hline & & $(0.217)$ & & \\
\hline \multirow[t]{2}{*}{ Economic Reason } & & & 0.266 & \\
\hline & & & $(0.146)^{*}$ & \\
\hline \multirow[t]{2}{*}{ Civil Servant } & & & & 0.004 \\
\hline & & & & $(0.250)$ \\
\hline \multirow[t]{2}{*}{ Business Sales } & & & & -0.135 \\
\hline & & & & $(0.156)$ \\
\hline \multirow[t]{2}{*}{ Craft and Trade Workers } & & & & -0.349 \\
\hline & & & & $(0.252)$ \\
\hline \multirow[t]{2}{*}{ Elementary Occupation } & & & & 0.416 \\
\hline & & & & $(0.192)^{* *}$ \\
\hline \multirow[t]{2}{*}{ Other Sources of Income } & & & & -0.972 \\
\hline & & & & $(0.502)^{*}$ \\
\hline \multirow[t]{2}{*}{ Constant } & -0.519 & -0.650 & -0.731 & -0.475 \\
\hline & $(0.493)$ & $(0.542)$ & $(0.517)$ & $(0.520)$ \\
\hline \multirow[t]{2}{*}{ Country Variance } & 0.855 & 1.014 & 0.952 & 0.966 \\
\hline & $(0.591)$ & $(0.667)$ & $(0.645)$ & $(0.656)$ \\
\hline \multirow[t]{2}{*}{ District Variance } & 0.125 & 0.026 & 0.130 & 0.132 \\
\hline & $(0.068)$ & $(0.059)$ & $(0.070)$ & $(0.071)$ \\
\hline Observations & 1,804 & 1,316 & 1,812 & 1,781 \\
\hline Number of Groups & 5 & 5 & 5 & 5 \\
\hline Log Likelihood & $-1,007.100$ & -728.280 & $-1,012.979$ & -993.773 \\
\hline Wald $\chi^{2}$ & $18.76^{* *}$ & $13.65^{*}$ & $16.40 * *$ & $26.79 * * *$ \\
\hline
\end{tabular}

Table entries are coefficients from multilevel logistic regression models with country level and district level random effects; standard errors in parentheses.

*** significant at $1 \%$;* significant at $5 \%$; significant at $10 \%$. 
Table 5. Environmental Conflict Multilevel Logistic Regression Models

\begin{tabular}{|c|c|c|c|c|}
\hline & $\begin{array}{c}\text { Model 13 } \\
\text { (Environmental) }\end{array}$ & $\begin{array}{c}\text { Model 14 } \\
\text { (Environmental) }\end{array}$ & $\begin{array}{c}\text { Model 15 } \\
\text { (Environmental) }\end{array}$ & $\begin{array}{c}\text { Model } 16 \\
\text { (Environmental) }\end{array}$ \\
\hline Sudden, Short-Term Events & $\begin{array}{l}-0.233 \\
(0.195)\end{array}$ & $\begin{array}{l}-0.269 \\
(0.206)\end{array}$ & $\begin{array}{l}-0.255 \\
(0.194)\end{array}$ & $\begin{array}{l}-0.239 \\
(0.200)\end{array}$ \\
\hline Gradual, Long-Term Events & $\begin{array}{c}0.875 \\
(0.216)^{* * *}\end{array}$ & $\begin{array}{c}0.918 \\
(0.250)^{* * *}\end{array}$ & $\begin{array}{c}0.888 \\
(0.215)^{* * *}\end{array}$ & $\begin{array}{c}0.853 \\
(0.221)^{* * *}\end{array}$ \\
\hline Female & $\begin{array}{c}0.166 \\
(0.153)\end{array}$ & $\begin{array}{c}0.112 \\
(0.172)\end{array}$ & $\begin{array}{c}0.174 \\
(0.150)\end{array}$ & $\begin{array}{c}0.221 \\
(0.154)\end{array}$ \\
\hline Age & $\begin{array}{c}0.002 \\
(0.008)\end{array}$ & $\begin{array}{c}0.001 \\
(0.008)\end{array}$ & $\begin{array}{c}0.001 \\
(0.008)\end{array}$ & $\begin{array}{l}-0.001 \\
(0.008)\end{array}$ \\
\hline Household Member Migrated & $\begin{array}{c}0.059 \\
(0.152)\end{array}$ & $\begin{array}{c}0.122 \\
(0.173)\end{array}$ & $\begin{array}{l}0.067 \\
(0.152)\end{array}$ & $\begin{array}{c}0.056 \\
(0.155)\end{array}$ \\
\hline No Education & $\begin{array}{l}-0.029 \\
(0.324)\end{array}$ & & & \\
\hline Primary Education & $\begin{array}{l}-0.038 \\
(0.284)\end{array}$ & & & \\
\hline Secondary Education & $\begin{array}{l}-0.203 \\
(0.215)\end{array}$ & & & \\
\hline Poor Household & & $\begin{array}{c}0.789 \\
(0.239)^{* * *}\end{array}$ & & \\
\hline Rich Household & & $\begin{array}{l}-0.462 \\
(0.352)\end{array}$ & & \\
\hline Economic Reason & & & $\begin{array}{l}0.162 \\
(0.194)\end{array}$ & \\
\hline Civil Servant & & & & $\begin{array}{l}-0.132 \\
(0.394)\end{array}$ \\
\hline Business Sales & & & & $\begin{array}{l}0.012 \\
(0.200)\end{array}$ \\
\hline Craft and Trade Workers & & & & $\begin{array}{l}-0.284 \\
(0.341)\end{array}$ \\
\hline Elementary Occupation & & & & $\begin{array}{l}-0.126 \\
(0.262)\end{array}$ \\
\hline Other Sources of Income & & & & $\begin{array}{l}0.082 \\
(0.650)\end{array}$ \\
\hline Constant & $\begin{array}{c}-2.357 \\
(0.452)^{* * *}\end{array}$ & $\begin{array}{c}-2.802 \\
(0.508)^{* * * *}\end{array}$ & $\begin{array}{c}-2.534 \\
(0.457)^{* * *}\end{array}$ & $\begin{array}{c}-2.313 \\
(0.468)^{* * *}\end{array}$ \\
\hline Country Variance & $\begin{array}{c}0.322 \\
(0.347)\end{array}$ & $\begin{array}{c}0.389 \\
(0.372)\end{array}$ & $\begin{array}{c}0.311 \\
(0.326)\end{array}$ & $\begin{array}{c}0.361 \\
(0.358)\end{array}$ \\
\hline District Variance & $\begin{array}{c}0.562 \\
(0.255)\end{array}$ & $\begin{array}{c}0.492 \\
(0.258)\end{array}$ & $\begin{array}{c}0.553 \\
(0.251)\end{array}$ & $\begin{array}{c}0.551 \\
(0.251)\end{array}$ \\
\hline Observations & 1,804 & 1,316 & 1,812 & 1,781 \\
\hline Number of Groups & 5 & 5 & 5 & 5 \\
\hline Log Likelihood & -656.969 & -509.258 & -661.467 & -993.773 \\
\hline Wald $\chi^{2}$ & $21.65 * * *$ & $37.09 * * *$ & $22.67 * * *$ & $26.79 * * *$ \\
\hline
\end{tabular}

Table entries are coefficients from multilevel logistic regression models with country level and district level random effects; standard errors in parentheses.

*** significant at $1 \%$;* significant at $5 \%$; significant at $10 \%$. 
Table 6. Political Conflict Multilevel Logistic Regression Models

\begin{tabular}{|c|c|c|c|c|}
\hline & $\begin{array}{l}\text { Model } 17 \\
\text { (Political) }\end{array}$ & $\begin{array}{l}\text { Model } 18 \\
\text { (Political) }\end{array}$ & $\begin{array}{l}\text { Model } 19 \\
\text { (Political) }\end{array}$ & $\begin{array}{l}\text { Model } 20 \\
\text { (Political) }\end{array}$ \\
\hline Sudden, Short-Term Events & $\begin{array}{c}0.402 \\
(0.358)\end{array}$ & $\begin{array}{c}0.500 \\
(0.363)\end{array}$ & $\begin{array}{c}0.433 \\
(0.355)\end{array}$ & $\begin{array}{c}0.489 \\
(0.361)\end{array}$ \\
\hline Gradual, Long-Term Events & $\begin{array}{c}0.959 \\
(0.463)^{* *}\end{array}$ & $\begin{array}{c}1.101 \\
(0.525)^{* *}\end{array}$ & $\begin{array}{c}0.951 \\
(0.465)^{* *}\end{array}$ & $\begin{array}{c}0.947 \\
(0.475)^{* *}\end{array}$ \\
\hline Female & $\begin{array}{c}-0.710 \\
(0.311)^{* *}\end{array}$ & $\begin{array}{c}-0.670 \\
(0.316)^{* *}\end{array}$ & $\begin{array}{c}-0.685 \\
(0.302)^{* *}\end{array}$ & $\begin{array}{c}-0.718 \\
(0.303)^{* *}\end{array}$ \\
\hline Age & $\begin{array}{c}0.013 \\
(0.016)\end{array}$ & $\begin{array}{c}0.015 \\
(0.016)\end{array}$ & $\begin{array}{c}0.015 \\
(0.016)\end{array}$ & $\begin{array}{c}0.015 \\
(0.016)\end{array}$ \\
\hline Household Member Migrated & $\begin{array}{c}0.077 \\
(0.310)\end{array}$ & $\begin{array}{l}-0.014 \\
(0.329)\end{array}$ & $\begin{array}{l}0.073 \\
(0.309)\end{array}$ & $\begin{array}{c}0.141 \\
(0.311)\end{array}$ \\
\hline No Education & $\begin{array}{c}0.378 \\
(0.661)\end{array}$ & & & \\
\hline Primary Education & $\begin{array}{c}0.866 \\
(0.596)\end{array}$ & & & \\
\hline Secondary Education & $\begin{array}{c}0.125 \\
(0.568)\end{array}$ & & & \\
\hline Poor Household & & $\begin{array}{l}0.583 \\
(0.464)\end{array}$ & & \\
\hline Rich Household & & $\begin{array}{l}-0.597 \\
(0.829)\end{array}$ & & \\
\hline Economic Reason & & & $\begin{array}{l}0.182 \\
(0.419)\end{array}$ & \\
\hline Civil Servant & & & & $\begin{array}{c}0.537 \\
(0.660)\end{array}$ \\
\hline Business Sales & & & & $\begin{array}{l}0.096 \\
(0.422)\end{array}$ \\
\hline Craft and Trade Workers & & & & $\begin{array}{l}-1.090 \\
(1.042)\end{array}$ \\
\hline Elementary Occupation & & & & $\begin{array}{l}0.319 \\
(0.486)\end{array}$ \\
\hline Other Sources of Income & & & & $\begin{array}{l}0.406 \\
(1.093)\end{array}$ \\
\hline Constant & $\begin{array}{c}-5.135 \\
(0.838)^{* * *}\end{array}$ & $\begin{array}{c}-5.397 \\
(0.927)^{* * *}\end{array}$ & $\begin{array}{c}-5.114 \\
(0.864)^{* * *}\end{array}$ & $\begin{array}{c}-5.073 \\
(0.865)^{* * *}\end{array}$ \\
\hline Country Variance & $\begin{array}{c}0.688 \\
(0.643)\end{array}$ & $\begin{array}{c}0.874 \\
(0.863)\end{array}$ & $\begin{array}{c}0.906 \\
(0.720)\end{array}$ & $\begin{array}{c}1.063 \\
(0.815)\end{array}$ \\
\hline District Variance & $\begin{array}{c}0.052 \\
(0.139)\end{array}$ & $\begin{array}{c}0.000 \\
(0.000)\end{array}$ & $\begin{array}{c}0.014 \\
(0.101)\end{array}$ & $\begin{array}{c}0.000 \\
(0.000)\end{array}$ \\
\hline Observations & 1,804 & 1,316 & 1,812 & 1,781 \\
\hline Number of Groups & 5 & 5 & 5 & 5 \\
\hline Log Likelihood & -193.592 & -170.740 & -195.779 & -191.127 \\
\hline Wald $\chi^{2}$ & $14.67 *$ & $12.22 *$ & $11.45^{*}$ & 13.45 \\
\hline
\end{tabular}

Table entries are coefficients from multilevel logistic regression models with country level and district level random effects; standard errors in parentheses.

*** significant at $1 \%$;* significant at $5 \%$; significant at $10 \%$. 
Figure 1. Overview of Theoretical Framework

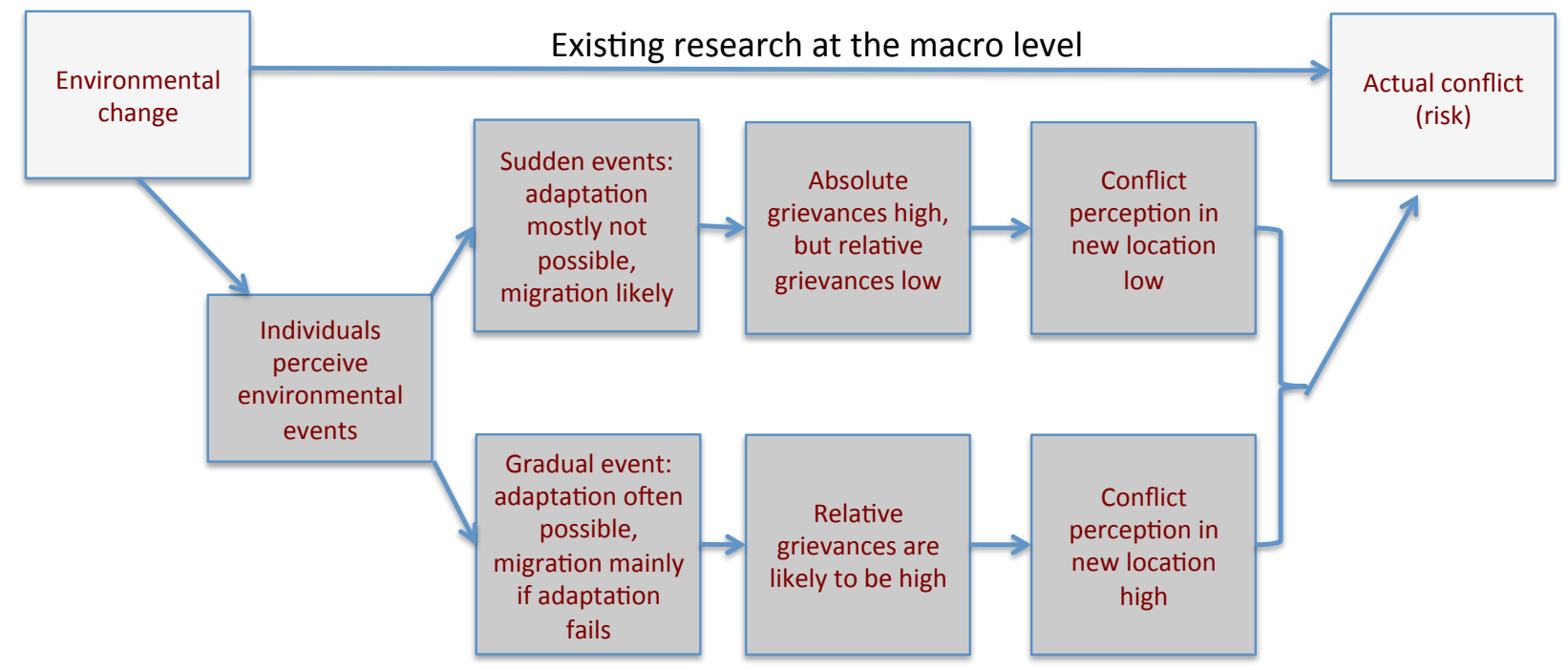


Figure 2. The Probability of Conflict Perception for Gradual, Long-term Events

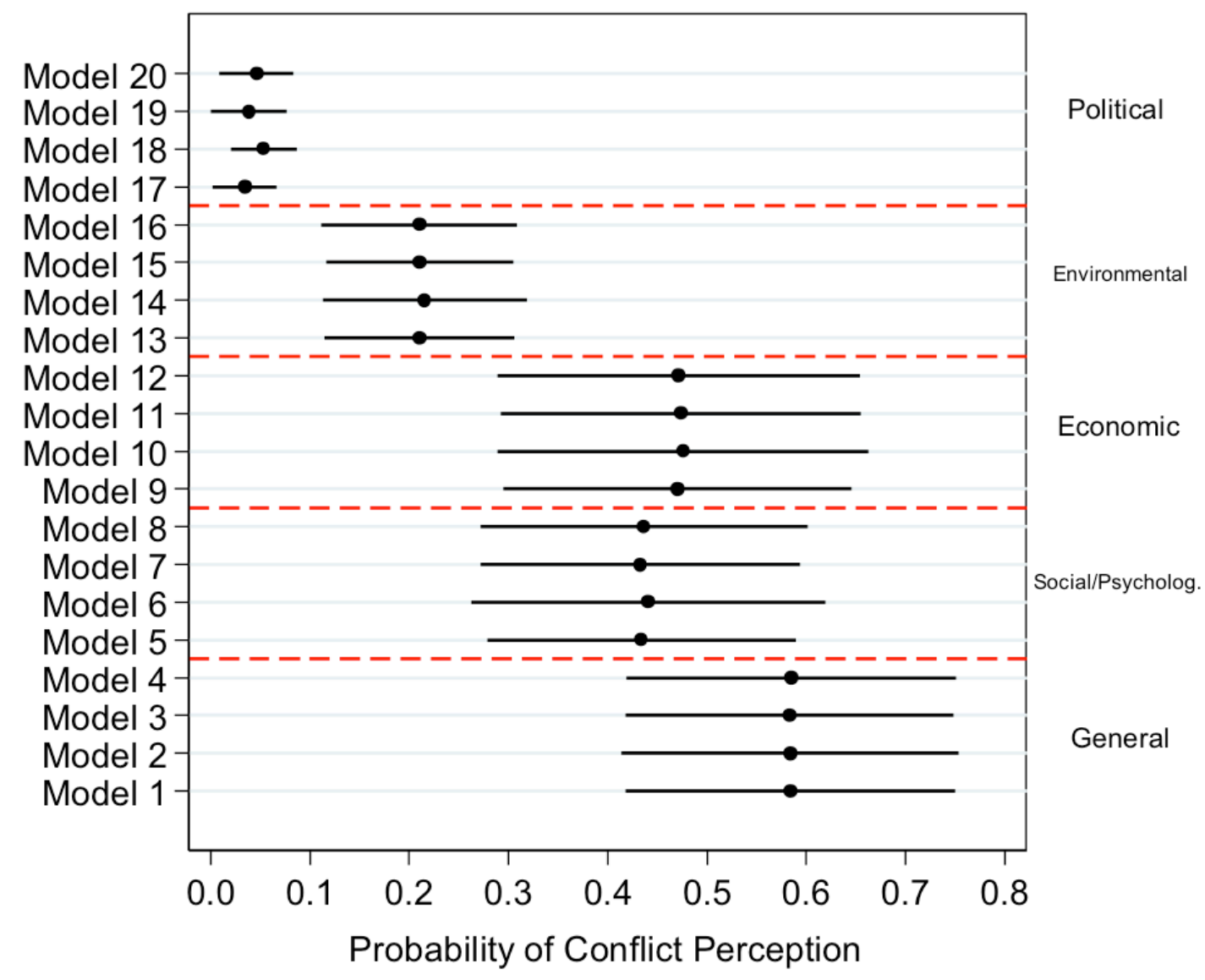

Graph shows predicted probabilities for the value of 1 for the five different dependent variables while Gradual, Long-Term Events=1; horizontal bars pertain to 95\% confidence intervals; all other variables held constant at their means; calculations are based on Tables 2-6 where we consider both fixed and random effects. 


\section{The Determinants of Environmental Migrants' Conflict Perception}

\section{- Online Appendix}

In order to ensure the robustness of our results, we changed a variety of model specifications and re-run the estimations. In the following, we briefly discuss these changes and corresponding results that further support our theory and results of the main text. ${ }^{86}$ These include:

- Appendix Table 1 re-estimates the core empirical models in the main text while including interactions of the environmental events variables with an item on political exclusion.

- Appendix Table 2 summarizes models that are based on a more constrained sample of rather inclusive states only.

- Appendix Table 3 focuses on individuals that only recently arrived at their new location of residence.

- Appendix Table 4 focuses on a heckman-type probit selection model on the decision to migrate and conflict perceptions.

- Appendix Table 5 omits all control covariates for the model estimation.

- Appendix Table 6 additionally incorporates two country-level covariates.

- Appendix Table 7 summarizes the main models while interacting the environmental events variables with political regime type.

- Appendix Table 8 summarizes the main models while interacting the environmental events variables with GDP per capita.

- Appendix Table 9 re-estimates the main models with logistic regression and country fixed effects.

\footnotetext{
${ }^{86}$ We mostly present only re-estimations of Table 2 from the main text, i.e., the general conflict perception variable. The models based on the other dependent variables produce qualitatively the same results as those discussed here, and can be replicated with our replication materials. The data and replication instructions can be obtained from the authors on request.
} 
The appendix concludes with an overview of the locations of the surveys, including maps (Figures A1-A5), and the questionnaire we used for our interviews. First, in the models presented above, we do not explicitly examine conditional effects capturing interactive relationships between the determinants of migration at different levels (micro, macro, and meso) as Hunter, Luna, and Norton describe these relationships as "additive." ${ }^{87}$ We plan on investigating these conditional relationships more thoroughly in a subsequent project, although we conducted some preliminary analyses with an interaction of the environmental-event variables and an item on political exclusion. Specifically, Buhaug, Cederman, and Gleditsch ${ }^{88}$ report that the probability of conflict increases when a specific ethnic group is on average poorer than the country as a whole. In a related fashion, Cederman, Weidmann, and Gleditsch ${ }^{89}$ focus on horizontal inequalities and ethnic groups, and find that in highly unequal societies both affluent and poor groups relative to the national average are more likely to engage in conflict. In light of these studies, it seems plausible that ethnicity affects conflict and, in the first place, conflict perceptions. We control for this possibility in two ways.

On one hand, the country- and regional-level random intercepts capture these influences at the levels above the individual. This strategy is effective if all/most respondents do actually have the same ethnic background, which is largely given in our sample data, although some variation does exist in the countries as well. On the other hand, an alternative mechanism that leads to more conflictive perceptions could be that individuals are more conflict-prone and aggressive if there is an actor who is the "perpetrator of environmental degradation" - but the type of the environmental event may matter less. ${ }^{90}$ Hence, the theoretical mechanism behind conflict perceptions could simply be about "who is to blame."

\footnotetext{
${ }^{87}$ Hunter, Luna, and Norton 2015, 9.

${ }^{88}$ Buhaug, Cederman, and Gleditsch 2014.

${ }^{89}$ Cederman, Weidmann, and Gleditsch 2011.

${ }^{90} \mathrm{We}$ thank an anonymous reviewer for this suggestion.
} 
We decided to address this concern with data on ethnicity and ethnic exclusion. More specifically, our survey data include information on the ethnic group an individual belongs to. ${ }^{91}$ We combined this information with the Ethnic Power Relations (EPR) data set, ${ }^{92}$ which identifies all politically relevant ethnic groups and their access to state power in every country since 1946. Eventually, we are able to code whether an individual belongs to an ethnic group that is politically included or one that is excluded, i.e., when it is politically powerless, when group members are subject to active and intentional discrimination by the state, or when a group excludes itself from power ("separatist autonomy"). When incorporating this additional variable into our models and interacting it with the environmental-events variables, we can capture the mechanism that the grievance toward some actor to blame (i.e., the included group or the state) might either be more relevant than or moderate the effect of the environmental-events items. We re-estimated all models with this additional variable and its interactive specification. The corresponding results, which we summarize for the general conflict-perception variable in Table A1, show that while the political-exclusion variable is insignificant, our main finding that gradual, long-term environmental changes positively and significantly affects migrants' conflict perceptions does hold. Moreover, the multiplicative terms are largely insignificant. This lends little support to the claim that a conditional effect does exist. However, other interactive relationships may be given in our data set and we seek to address this in the future.

Table A1 here

Related to this, it might be possible that people move from a relatively "benign environment" to a more hostile one (or vice versa), and that this affects conflict perceptions in turn. Given the

\footnotetext{
${ }^{91}$ Specifically, the exact survey question is: "which ethnic group do you belong to?"

${ }^{92}$ Cederman, Wimmer, and Min 2010; Vogt et al. 2015.
} 
information that our survey offers and the data from the EPR, ${ }^{93}$ we obtained the variable "size of the excluded population in a country" from the EPR data (in the year 2012). After having determined the mean value of this item in our sample $(0.172)$, we dropped those countries that had excluded populations above that average value. Ultimately, we thus constrain our data to a sample of countries, which are relatively inclusive throughout their societies, their sub-regions, districts, and towns. Hence, the degree of political inclusion in that constrained sample is fairly constant then, since we dropped those cases in which people could move from a more inclusive area to a more excluded one (or vice versa). Afterwards, we re-estimated our models with this constrained, but overall relatively inclusive sample of individuals and countries. The main result for Gradual, Long-Term Events should hold with this sample as well (i.e., a sample that then basically captures "same-level-of-inclusion" within-country migration). Again, as demonstrated in Table A2, our core result remains robust as the positive and statistically significant effect of gradual, long-term events is still given.

Table A2 here

Third, and coming back to the main text, we repeated our analysis focusing on migrants that arrived rather shortly to their new location. This allows us to rule out a strong influence at the "new home" on conflict perceptions. To this end, we use a variable that measures how long a migrant has lived in his/her new location. We only include those migrants that are part of the lower 10 percent of that variables' distribution (274 migrants; average duration spent in new location=0.986 years). The results (Table A3) show that Gradual, Long-Term Events remains to be positively signed and statistically significant, which increases the confidence in the validity of our findings and argument.

\footnotetext{
${ }^{93}$ Cederman, Wimmer, and Min 2010; Vogt et al. 2015.
} 
Fourth, migrants are not a random sample of individuals. In the models above, we partly control for this circumstance with the Economic Reason item and other controls that may well have affected an individuals' decision to migrate in the first place. However, the reasons to migrate may be more multi-faceted and there could also be unobserved determinants affecting an individual's decision to stay or move. If these variables related the migration decision also affect a migrant's perception of conflict, we may either over- or underestimate the effect of our core explanatory variables. In order to address this issue thoroughly, we created a data set comprising both migrants and non-migrants (i.e., individuals who decided to stay in the migrant's previous location). Afterwards, we relied on a Heckman-type selection model for binary data (Heckman Probit Model), for which we had to specify a selection variable and a binary outcome.

The binary outcome variable is one of those dependent variables used for the core models above, while we rely on a binary migration variable ( $1=$ migrated; $0=$ not migrated) to capture sample selection. As Heckman-type models require that there must be at least one variable in the selection equation that does not appear in the outcome equation, we only include our core variables of interest (Sudden, Short-Term Events and Gradual, Long-Term Events) as well as any of the statistically significant controls from the main text's Tables 2-6 in the outcome equation. For example, Female does not exert a statistically significant impact in Table 2, but in Models 58 (Table 3 in the main text). Hence, for the selection models based on Table 2, we only include Female in the selection equation, while this item is included in both the selection and outcome equation of those selection models that are based on the main article's Table 3. Eventually, this ensures that the model is identified. That said, when estimating these selection models, our core results are not affected by this change in the estimation strategy; moreover, the coefficient 
capturing the correlation in the two equations' error terms is mainly insignificant across estimations, suggesting that sample selection is of minor importance in our context.

Table A4 here

Fifth, one major concern could be that the environmental-events estimates are affected by the inclusion or exclusion of potentially endogenous factors. In fact, Clarke shows that including control variables in models can actually increase the bias. ${ }^{94}$ However, when omitting all control covariates in our models and only including the environmental-events items as explanatory variables, the effect of gradual, long-term and sudden, short-term events, respectively, does virtually not change across the regressions (Table A5). We are therefore confident that the effect of gradual, long-term events is indeed unbiased.

Table A5 here

Sixth, by incorporating country-level and regional-level random intercepts, we control for the fact that we study internal migration in five country contexts as well as in diverse regional settings. However, one could model these different contexts more directly by including relevant factors that might affect migration patterns within countries. Two factors seem most relevant from this perspective: a nation's political system and a country's economic development. Both influences could affect a country's capability to react to specific environmental events and, thus, migrants' conflict perceptions. We thus considered a variable on a country's political system, measured by the polity 2 variable from the Polity IV data, ${ }^{95}$ and GDP per capita in current US Dollars as taken from the World Bank Development Indicators. For both items, we use data from

\footnotetext{
${ }^{94}$ Clarke 2005, 2009.

${ }^{95}$ Marshall, Jaggers, and Gurr 2013.
} 
2012 to ensure that they are measured before the surveys were conducted. When incorporating these country-level controls, the results show that basically none of them has a significant effect either for the aggregated or the disaggregated dependent variables (Table A6). Finally, we also examined the possibility of interactive effects, mirroring the rationale behind Table A1 to some extent. As demonstrated in Tables A7-A8, however, this does also not question our main finding.

Finally, it has been suggested to re-estimate our main models with "regular" logistic regression and country fixed effects. Such an approach could indicate where we see a stronger link at a country level, and this might be more accurately than the multi-level setup in the main text that merely controls for country-level variance and the robustness check above that incorporates country-level covariates (democracy and income). Table A9 summarizes our findings for this last robustness check (based on Model 1 of the main text; the findings are qualitatively the same for all other models). Furthermore, while logistic regression models with country dummies are inconsistent if the number of observations per country is not large enough, the results are identical if we employ a conditional logistic regression instead.

Table A9 here

On one hand, the main conclusion of our research pertaining to gradual, long-term environmental events is unchanged. On the other hand, all fixed effects are positively signed and statistically significant, and this result in Table A9 is representative of all other models discussed above when including fixed effects there. This emphasizes that these countries differ from the baseline, i.e., Nicaragua, in important ways. It may thus be an effort worth making in future research to focus on that country as the likelihood of conflict perceptions seems to be systematically lower there than elsewhere. 
Table A1. General Conflict Perception Multilevel Logistic Regression Models

\begin{tabular}{|c|c|c|c|c|}
\hline & $\begin{array}{c}\text { Model } 1 \\
\text { (Conflict } \\
\text { Perception) } \\
\end{array}$ & $\begin{array}{c}\text { Model } 2 \\
\text { (Conflict } \\
\text { Perception) }\end{array}$ & $\begin{array}{c}\text { Model } 3 \\
\text { (Conflict } \\
\text { Perception) }\end{array}$ & $\begin{array}{c}\text { Model } 4 \\
\text { (Conflict } \\
\text { Perception) }\end{array}$ \\
\hline Sudden, Short-Term Events & $\begin{array}{c}0.236 \\
(0.183)\end{array}$ & $\begin{array}{c}0.186 \\
(0.205)\end{array}$ & $\begin{array}{c}0.219 \\
(0.183)\end{array}$ & $\begin{array}{c}0.213 \\
(0.184)\end{array}$ \\
\hline Gradual, Long-Term Events & $\begin{array}{c}0.434 \\
(0.146)^{* * *}\end{array}$ & $\begin{array}{c}0.319 \\
(0.178)^{*}\end{array}$ & $\begin{array}{c}0.450 \\
(0.146)^{* * *}\end{array}$ & $\begin{array}{c}0.451 \\
(0.147)^{* * *}\end{array}$ \\
\hline Political Exclusion & $\begin{array}{c}0.671 \\
(0.651)\end{array}$ & $\begin{array}{c}0.844 \\
(0.666)\end{array}$ & $\begin{array}{c}0.714 \\
(0.650)\end{array}$ & $\begin{array}{c}0.682 \\
(0.655)\end{array}$ \\
\hline Sudden, Short-Term Events * Political Exclusion & $\begin{array}{l}-1.000 \\
(0.692)\end{array}$ & $\begin{array}{c}-1.226 \\
(0.731)^{*}\end{array}$ & $\begin{array}{l}-1.042 \\
(0.693)\end{array}$ & $\begin{array}{l}-1.025 \\
(0.695)\end{array}$ \\
\hline Gradual, Long-Term Events * Political Exclusion & $\begin{array}{l}-0.263 \\
(0.680)\end{array}$ & $\begin{array}{l}-0.552 \\
(0.825)\end{array}$ & $\begin{array}{c}-0.192 \\
(0.684)\end{array}$ & $\begin{array}{l}-0.190 \\
(0.684)\end{array}$ \\
\hline Female & $\begin{array}{c}0.034 \\
(0.118)\end{array}$ & $\begin{array}{c}0.019 \\
(0.147)\end{array}$ & $\begin{array}{c}0.008 \\
(0.117)\end{array}$ & $\begin{array}{l}-0.005 \\
(0.117)\end{array}$ \\
\hline Age & $\begin{array}{l}-0.002 \\
(0.007)\end{array}$ & $\begin{array}{l}-0.004 \\
(0.007)\end{array}$ & $\begin{array}{l}-0.009 \\
(0.006)\end{array}$ & $\begin{array}{l}-0.008 \\
(0.006)\end{array}$ \\
\hline Household Member Migrated & $\begin{array}{c}-0.214 \\
(0.117)^{*}\end{array}$ & $\begin{array}{l}-0.152 \\
(0.143)\end{array}$ & $\begin{array}{c}-0.203 \\
(0.116)^{*}\end{array}$ & $\begin{array}{c}-0.192 \\
(0.117)^{*}\end{array}$ \\
\hline No Education & $\begin{array}{l}-0.659 \\
(0.419)\end{array}$ & & & \\
\hline Primary Education & $\begin{array}{c}-0.375 \\
(0.212)^{*}\end{array}$ & & & \\
\hline Secondary Education & $\begin{array}{c}-0.319 \\
(0.131)^{* *}\end{array}$ & & & \\
\hline Poor Household & & $\begin{array}{c}0.194 \\
(0.197)\end{array}$ & & \\
\hline Rich Household & & $\begin{array}{l}-0.113 \\
(0.224)\end{array}$ & & \\
\hline Economic Reason & & & $\begin{array}{l}0.123 \\
(0.147)\end{array}$ & \\
\hline Civil Servant & & & & $\begin{array}{c}0.144 \\
(0.239)\end{array}$ \\
\hline Business Sales & & & & $\begin{array}{l}0.005 \\
(0.158)\end{array}$ \\
\hline Craft and Trade Workers & & & & $\begin{array}{l}-0.208 \\
(0.239)\end{array}$ \\
\hline Elementary Occupation & & & & $\begin{array}{c}0.147 \\
(0.199)\end{array}$ \\
\hline Other Sources of Income & & & & $\begin{array}{l}-0.287 \\
(0.364)\end{array}$ \\
\hline Constant & $\begin{array}{l}-0.297 \\
(0.315)\end{array}$ & $\begin{array}{l}-0.439 \\
(0.378)\end{array}$ & $\begin{array}{l}-0.380 \\
(0.333)\end{array}$ & $\begin{array}{l}-0.295 \\
(0.331)\end{array}$ \\
\hline Country Variance & $\begin{array}{c}0.057 \\
(0.083)\end{array}$ & $\begin{array}{c}0.136 \\
(0.142)\end{array}$ & $\begin{array}{c}0.089 \\
(0.105)\end{array}$ & $\begin{array}{c}0.086 \\
(0.105)\end{array}$ \\
\hline District Variance & $\begin{array}{c}0.177 \\
(0.082)\end{array}$ & $\begin{array}{c}0.115 \\
(0.076)\end{array}$ & $\begin{array}{c}0.178 \\
(0.082)\end{array}$ & $\begin{array}{c}0.182 \\
(0.084)\end{array}$ \\
\hline Observations & 1,440 & 949 & 1,441 & 1,441 \\
\hline Number of Groups & 4 & 4 & 4 & 4 \\
\hline Log Likelihood & -929.041 & -625.565 & -932.749 & -931.719 \\
\hline Wald $\chi^{2}$ & $23.58 * *$ & 9.10 & $17.09 * *$ & 19.01 \\
\hline
\end{tabular}

Table entries are coefficients from multilevel logistic regression models with country level and district level random effects; standard errors in parentheses.

$* * *$ significant at $1 \% ; * *$ significant at $5 \% ; *$ significant at $10 \%$. 
Table A2. General Conflict Perception - Constrained Sample (More Inclusive States)

\begin{tabular}{|c|c|c|c|c|}
\hline & $\begin{array}{c}\text { Model } 5 \\
\text { (Conflict } \\
\text { Perception) }\end{array}$ & $\begin{array}{c}\text { Model } 6 \\
\text { (Conflict } \\
\text { Perception) }\end{array}$ & $\begin{array}{c}\text { Model } 7 \\
\text { (Conflict } \\
\text { Perception) }\end{array}$ & $\begin{array}{c}\text { Model } 8 \\
\text { (Conflict } \\
\text { Perception) }\end{array}$ \\
\hline Sudden, Short-Term Events & $\begin{array}{c}0.147 \\
(0.211)\end{array}$ & $\begin{array}{l}-0.038 \\
(0.244)\end{array}$ & $\begin{array}{c}0.097 \\
(0.211)\end{array}$ & $\begin{array}{c}0.088 \\
(0.211)\end{array}$ \\
\hline Gradual, Long-Term Events & $\begin{array}{c}0.533 \\
(0.153)^{* * *}\end{array}$ & $\begin{array}{c}0.431 \\
(0.189)^{* *}\end{array}$ & $\begin{array}{c}0.553 \\
(0.152)^{* * *}\end{array}$ & $\begin{array}{c}0.555 \\
(0.152)^{* * *}\end{array}$ \\
\hline Female & $\begin{array}{c}0.039 \\
(0.129)\end{array}$ & $\begin{array}{c}0.027 \\
(0.172)\end{array}$ & $\begin{array}{c}0.003 \\
(0.128)\end{array}$ & $\begin{array}{l}-0.002 \\
(0.129)\end{array}$ \\
\hline Age & $\begin{array}{l}-0.004 \\
(0.008)\end{array}$ & $\begin{array}{l}-0.007 \\
(0.009)\end{array}$ & $\begin{array}{c}-0.013 \\
(0.008)^{*}\end{array}$ & $\begin{array}{c}-0.013 \\
(0.008)^{*}\end{array}$ \\
\hline Household Member Migrated & $\begin{array}{c}-0.272 \\
(0.130)^{* *}\end{array}$ & $\begin{array}{l}-0.214 \\
(0.168)\end{array}$ & $\begin{array}{c}-0.254 \\
(0.129)^{* *}\end{array}$ & $\begin{array}{c}-0.250 \\
(0.130)^{*}\end{array}$ \\
\hline No Education & $\begin{array}{c}-0.826 \\
(0.452)^{*}\end{array}$ & & & \\
\hline Primary Education & $\begin{array}{c}-0.666 \\
(0.247)^{* * *}\end{array}$ & & & \\
\hline Secondary Education & $\begin{array}{c}-0.444 \\
(0.148)^{* * *}\end{array}$ & & & \\
\hline Poor Household & & $\begin{array}{l}0.414 \\
(0.261)\end{array}$ & & \\
\hline Rich Household & & $\begin{array}{l}-0.149 \\
(0.233)\end{array}$ & & \\
\hline Economic Reason & & & $\begin{array}{l}-0.027 \\
(0.177)\end{array}$ & \\
\hline Civil Servant & & & & $\begin{array}{c}0.085 \\
(0.264)\end{array}$ \\
\hline Business Sales & & & & $\begin{array}{l}0.037 \\
(0.177)\end{array}$ \\
\hline Craft and Trade Workers & & & & $\begin{array}{l}-0.129 \\
(0.269)\end{array}$ \\
\hline Elementary Occupation & & & & $\begin{array}{c}0.177 \\
(0.232)\end{array}$ \\
\hline Other Sources of Income & & & & $\begin{array}{l}0.221 \\
(0.450)\end{array}$ \\
\hline Constant & $\begin{array}{l}-0.211 \\
(0.358)\end{array}$ & $\begin{array}{l}-0.323 \\
(0.524)\end{array}$ & $\begin{array}{l}-0.178 \\
(0.404)\end{array}$ & $\begin{array}{l}-0.216 \\
(0.398)\end{array}$ \\
\hline Country Variance & $\begin{array}{c}0.041 \\
(0.079)\end{array}$ & $\begin{array}{c}0.335 \\
(0.332)\end{array}$ & $\begin{array}{c}0.110 \\
(0.137)\end{array}$ & $\begin{array}{c}0.118 \\
(0.147)\end{array}$ \\
\hline District Variance & $\begin{array}{c}0.176 \\
(0.089)\end{array}$ & $\begin{array}{c}0.082 \\
(0.078)\end{array}$ & $\begin{array}{c}0.182 \\
(0.092)\end{array}$ & $\begin{array}{c}0.191 \\
(0.096)\end{array}$ \\
\hline Observations & 1,190 & 699 & 1,191 & 1,191 \\
\hline Number of Groups & 3 & 3 & 3 & 3 \\
\hline Log Likelihood & -747.671 & -447.057 & -754.313 & -753.680 \\
\hline Wald $\chi^{2}$ & $31.22 * * *$ & 11.32 & $19.54 * * *$ & $20.72 * *$ \\
\hline
\end{tabular}

Table entries are coefficients from multilevel logistic regression models with country level and district level random effects; standard errors in parentheses.

$* * *$ significant at $1 \% ; * *$ significant at $5 \% ; *$ significant at $10 \%$. 
Table A3. General Conflict Perception - Constrained Sample (More "Recent" Migrants)

\begin{tabular}{|c|c|c|c|c|}
\hline & $\begin{array}{c}\text { Model } 9 \\
\text { (Conflict } \\
\text { Perception) }\end{array}$ & $\begin{array}{l}\text { Model } 10 \\
\text { (Conflict } \\
\text { Perception) }\end{array}$ & $\begin{array}{l}\text { Model } 11 \\
\text { (Conflict } \\
\text { Perception) }\end{array}$ & $\begin{array}{l}\text { Model } 12 \\
\text { (Conflict } \\
\text { Perception) }\end{array}$ \\
\hline Sudden, Short-Term Events & $\begin{array}{l}-0.689 \\
(0.372)\end{array}$ & $\begin{array}{c}-0.841 \\
(0.434)^{*}\end{array}$ & $\begin{array}{c}-0.663 \\
(0.395)^{*}\end{array}$ & $\begin{array}{l}-0.619 \\
(0.422)\end{array}$ \\
\hline Gradual, Long-Term Events & $\begin{array}{c}0.765 \\
(0.347)^{* *}\end{array}$ & $\begin{array}{c}0.760 \\
(0.427)^{*}\end{array}$ & $\begin{array}{c}0.847 \\
(0.367)^{* *}\end{array}$ & $\begin{array}{c}0.786 \\
(0.376)^{* *}\end{array}$ \\
\hline Female & $\begin{array}{c}0.017 \\
(0.316)\end{array}$ & $\begin{array}{l}-0.025 \\
(0.382)\end{array}$ & $\begin{array}{c}0.006 \\
(0.316)\end{array}$ & $\begin{array}{c}0.129 \\
(0.321)\end{array}$ \\
\hline Age & $\begin{array}{c}0.013 \\
(0.019)\end{array}$ & $\begin{array}{c}0.024 \\
(0.019)\end{array}$ & $\begin{array}{c}0.017 \\
(0.018)\end{array}$ & $\begin{array}{c}0.010 \\
(0.019)\end{array}$ \\
\hline Household Member Migrated & $\begin{array}{l}-0.202 \\
(0.313)\end{array}$ & $\begin{array}{l}-0.635 \\
(0.408)\end{array}$ & $\begin{array}{c}-0.178 \\
(0.313)\end{array}$ & $\begin{array}{l}-0.341 \\
(0.324)\end{array}$ \\
\hline No Education & $\begin{array}{c}0.185 \\
(0.627)\end{array}$ & & & \\
\hline Primary Education & $\begin{array}{l}-0.290 \\
(0.514)\end{array}$ & & & \\
\hline Secondary Education & $\begin{array}{c}-0.810 \\
(0.364)^{* *}\end{array}$ & & & \\
\hline Poor Household & & $\begin{array}{l}-0.612 \\
(0.454)\end{array}$ & & \\
\hline Rich Household & & $\begin{array}{l}-0.458 \\
(0.803)\end{array}$ & & \\
\hline Economic Reason & & & $\begin{array}{l}-0.556 \\
(0.350)\end{array}$ & \\
\hline Civil Servant & & & & $\begin{array}{c}0.335 \\
(0.639)\end{array}$ \\
\hline Business Sales & & & & $\begin{array}{c}0.389 \\
(0.450)\end{array}$ \\
\hline Craft and Trade Workers & & & & $\begin{array}{c}0.757 \\
(0.614)\end{array}$ \\
\hline Elementary Occupation & & & & $\begin{array}{c}0.676 \\
(0.469)\end{array}$ \\
\hline Other Sources of Income & & & & $\begin{array}{c}0.146 \\
(0.798)\end{array}$ \\
\hline Constant & $\begin{array}{l}-0.106 \\
(0.687)\end{array}$ & $\begin{array}{l}-0.056 \\
(0.836)\end{array}$ & $\begin{array}{l}-0.152 \\
(0.739)\end{array}$ & $\begin{array}{l}-0.544 \\
(0.763)\end{array}$ \\
\hline Country Variance & $\begin{array}{c}0.001 \\
(0.001)\end{array}$ & $\begin{array}{c}0.001 \\
(0.001)\end{array}$ & $\begin{array}{c}0.270 \\
(0.431)\end{array}$ & $\begin{array}{c}0.553 \\
(0.654)\end{array}$ \\
\hline District Variance & $\begin{array}{c}0.554 \\
(0.332)\end{array}$ & $\begin{array}{c}1.196 \\
(0.681)\end{array}$ & $\begin{array}{c}0.477 \\
(0.402)\end{array}$ & $\begin{array}{c}0.458 \\
(0.402)\end{array}$ \\
\hline Observations & 266 & 202 & 267 & 263 \\
\hline Number of Groups & 5 & 5 & 5 & 5 \\
\hline Log Likelihood & -152.643 & -113.793 & -154.548 & -150.744 \\
\hline Wald $\chi^{2}$ & $19.49 * *$ & $12.46^{*}$ & $11.59^{*}$ & 11.03 \\
\hline
\end{tabular}

Table entries are coefficients from multilevel logistic regression models with country level and district level random effects; standard errors in parentheses.

$* * *$ significant at $1 \% ; * *$ significant at $5 \% ; *$ significant at $10 \%$. 
Table A4. General Conflict Perception - Heckman-Probit Models

\begin{tabular}{|c|c|c|c|c|}
\hline & $\begin{array}{c}\text { Model } 13 \\
\text { (Conflict } \\
\text { Perception) }\end{array}$ & $\begin{array}{c}\text { Model } 14 \\
\text { (Conflict } \\
\text { Perception) }\end{array}$ & $\begin{array}{c}\text { Model } 15 \\
\text { (Conflict } \\
\text { Perception) }\end{array}$ & $\begin{array}{c}\text { Model } 16 \\
\text { (Conflict } \\
\text { Perception) }\end{array}$ \\
\hline Sudden, Short-Term Events & $\begin{array}{l}-0.212 \\
(0.188)\end{array}$ & $\begin{array}{l}-0.182 \\
(0.161)\end{array}$ & $\begin{array}{l}-0.268 \\
(0.255)\end{array}$ & $\begin{array}{l}-0.259 \\
(0.259)\end{array}$ \\
\hline Gradual, Long-Term Events & $\begin{array}{c}0.532 \\
(0.213)^{* *}\end{array}$ & $\begin{array}{c}0.659 \\
(0.281)^{* *}\end{array}$ & $\begin{array}{c}0.598 \\
(0.252)^{* *}\end{array}$ & $\begin{array}{c}0.601 \\
(0.266)^{* *}\end{array}$ \\
\hline Secondary Education & $\begin{array}{c}-0.311 \\
(0.150)^{*}\end{array}$ & & & \\
\hline Poor Household & & $\begin{array}{c}0.179 \\
(0.281)\end{array}$ & & \\
\hline Constant & $\begin{array}{l}-0.014 \\
(0.131)\end{array}$ & $\begin{array}{l}-0.126 \\
(0.164)\end{array}$ & $\begin{array}{l}-0.003 \\
(0.258)\end{array}$ & $\begin{array}{c}0.007 \\
(0.251)\end{array}$ \\
\hline Selection Equation (Migrant - 1/0) & & & & \\
\hline Sudden, Short-Term Events & $\begin{array}{c}0.035 \\
(0.303)\end{array}$ & $\begin{array}{l}-0.100 \\
(0.212)\end{array}$ & $\begin{array}{c}0.001 \\
(0.181)\end{array}$ & $\begin{array}{c}0.108 \\
(0.245)\end{array}$ \\
\hline Gradual, Long-Term Events & $\begin{array}{c}-0.239 \\
(0.103)^{* *}\end{array}$ & $\begin{array}{l}-0.150 \\
(0.138)\end{array}$ & $\begin{array}{c}-0.365 \\
(0.037)^{* * *}\end{array}$ & $\begin{array}{c}-0.311 \\
(0.060)^{* * *}\end{array}$ \\
\hline Female & $\begin{array}{c}0.082 \\
(0.154)\end{array}$ & $\begin{array}{c}0.106 \\
(0.145)\end{array}$ & $\begin{array}{c}0.144 \\
(0.160)\end{array}$ & $\begin{array}{c}0.035 \\
(0.154)\end{array}$ \\
\hline Age & $\begin{array}{c}-0.036 \\
(0.010)^{* * *}\end{array}$ & $\begin{array}{c}-0.037 \\
(0.012)^{* * *}\end{array}$ & $\begin{array}{c}-0.037 \\
(0.013)^{* * *}\end{array}$ & $\begin{array}{c}-0.045 \\
(0.015)^{* * *}\end{array}$ \\
\hline Household Member Migrated & $\begin{array}{c}0.100 \\
(0.140)\end{array}$ & $\begin{array}{c}0.107 \\
(0.157)\end{array}$ & $\begin{array}{c}0.033 \\
(0.117)\end{array}$ & $\begin{array}{c}0.128 \\
(0.148)\end{array}$ \\
\hline No Education & $\begin{array}{c}-0.743 \\
(0.383)^{*}\end{array}$ & & & \\
\hline Primary Education & $\begin{array}{c}-1.093 \\
(0.407)^{* * *}\end{array}$ & & & \\
\hline Secondary Education & $\begin{array}{c}-0.892 \\
(0.280)^{* * *}\end{array}$ & & & \\
\hline Poor Household & & $\begin{array}{l}-0.131 \\
(0.160)\end{array}$ & & \\
\hline Rich Household & & $\begin{array}{l}0.281 \\
(0.372)\end{array}$ & & \\
\hline Economic Reason & & & $\begin{array}{c}1.866 \\
(0.436)^{* * *}\end{array}$ & \\
\hline Civil Servant & & & & $\begin{array}{l}-0.229 \\
(0.145)\end{array}$ \\
\hline Business Sales & & & & $\begin{array}{c}-0.304 \\
(0.043)^{* * *}\end{array}$ \\
\hline Craft and Trade Workers & & & & $\begin{array}{c}-0.632 \\
(0.156)^{* * *}\end{array}$ \\
\hline Elementary Occupation & & & & $\begin{array}{c}-0.391 \\
(0.156)^{* *}\end{array}$ \\
\hline Other Sources of Income & & & & $\begin{array}{c}-0.231 \\
(0.137)^{*}\end{array}$ \\
\hline Constant & $\begin{array}{c}1.961 \\
(0.621)^{* * *}\end{array}$ & $\begin{array}{c}1.182 \\
(0.449)^{* * *}\end{array}$ & $\begin{array}{c}0.519 \\
(0.463)\end{array}$ & $\begin{array}{c}1.724 \\
(0.512)^{* * *}\end{array}$ \\
\hline Observations & 3,613 & 3,124 & 3,624 & 3,476 \\
\hline Log Likelihood & $-3,237.061$ & $-2,782.845$ & $-2,684.508$ & $-3,238.877$ \\
\hline Rho & 0.095 & -0.064 & -0.083 & -0.101 \\
\hline
\end{tabular}

Table entries are coefficients from heckman-probit regression models with; standard errors clustered on country in parentheses.

$* * *$ significant at $1 \% ; * *$ significant at $5 \% ; *$ significant at $10 \%$. 
Table A5. General Conflict Perception Multilevel Logistic Regression Models

\begin{tabular}{lc}
\hline & $\begin{array}{c}\text { Model 25 } \\
\text { (Conflict } \\
\text { Perception) }\end{array}$ \\
\hline Sudden, Short-Term Events & 0.120 \\
Gradual, Long-Term Events & $(0.159)$ \\
& 0.503 \\
Constant & $(0.137)^{* * *}$ \\
& \\
Country Variance & -0.188 \\
& $(0.429)$ \\
District Variance & 0.776 \\
& $(0.544)$ \\
Observations & 0.182 \\
Number of Groups & $(0.081)$ \\
Log Likelihood & \\
Wald $\chi^{2}$ & 1,842 \\
\hline
\end{tabular}

Table entries are coefficients from multilevel logistic regression models with country level and district level random effects; standard errors in parentheses.

$* * *$ significant at $1 \% ; * *$ significant at $5 \% ; *$ significant at $10 \%$. 
Table A6. General Conflict Perception Multilevel Logistic Regression Models - Country-Level Covariates

\begin{tabular}{|c|c|c|c|c|}
\hline & $\begin{array}{c}\text { Model } 26 \\
\text { (Conflict } \\
\text { Perception) }\end{array}$ & $\begin{array}{c}\text { Model } 27 \\
\text { (Conflict } \\
\text { Perception) }\end{array}$ & $\begin{array}{c}\text { Model } 28 \\
\text { (Conflict } \\
\text { Perception) }\end{array}$ & $\begin{array}{c}\text { Model 29 } \\
\text { (Conflict } \\
\text { Perception) } \\
\end{array}$ \\
\hline Sudden, Short-Term Events & $\begin{array}{c}0.117 \\
(0.161)\end{array}$ & $\begin{array}{c}0.051 \\
(0.173)\end{array}$ & $\begin{array}{c}0.118 \\
(0.160)\end{array}$ & $\begin{array}{c}0.085 \\
(0.162)\end{array}$ \\
\hline Gradual, Long-Term Events & $\begin{array}{c}0.493 \\
(0.139)^{* * *}\end{array}$ & $\begin{array}{c}0.393 \\
(0.165)^{* *}\end{array}$ & $\begin{array}{c}0.496 \\
(0.138)^{* * *}\end{array}$ & $\begin{array}{c}0.502 \\
(0.139)^{* * *}\end{array}$ \\
\hline Polity (Democracy) & $\begin{array}{l}-0.030 \\
(0.077)\end{array}$ & $\begin{array}{l}-0.073 \\
(0.070)\end{array}$ & $\begin{array}{l}-0.032 \\
(0.076)\end{array}$ & $\begin{array}{l}-0.033 \\
(0.077)\end{array}$ \\
\hline GDP per capita & $\begin{array}{l}-0.001 \\
(0.001)\end{array}$ & $\begin{array}{l}-0.001 \\
(0.001)\end{array}$ & $\begin{array}{l}-0.001 \\
(0.001)\end{array}$ & $\begin{array}{l}-0.001 \\
(0.001)\end{array}$ \\
\hline Female & $\begin{array}{c}0.094 \\
(0.111)\end{array}$ & $\begin{array}{c}0.113 \\
(0.135)\end{array}$ & $\begin{array}{c}0.090 \\
(0.110)\end{array}$ & $\begin{array}{c}0.094 \\
(0.111)\end{array}$ \\
\hline Age & $\begin{array}{l}-0.003 \\
(0.006)\end{array}$ & $\begin{array}{l}-0.005 \\
(0.007)\end{array}$ & $\begin{array}{l}-0.007 \\
(0.006)\end{array}$ & $\begin{array}{l}-0.009 \\
(0.006)\end{array}$ \\
\hline Household Member Migrated & $\begin{array}{l}-0.147 \\
(0.110)\end{array}$ & $\begin{array}{l}-0.039 \\
(0.133)\end{array}$ & $\begin{array}{l}-0.129 \\
(0.110)\end{array}$ & $\begin{array}{l}-0.132 \\
(0.111)\end{array}$ \\
\hline No Education & $\begin{array}{l}-0.165 \\
(0.292)\end{array}$ & & & \\
\hline Primary Education & $\begin{array}{l}-0.264 \\
(0.199)\end{array}$ & & & \\
\hline Secondary Education & $\begin{array}{c}-0.262 \\
(0.130)^{* *}\end{array}$ & & & \\
\hline Poor Household & & $\begin{array}{c}0.581 \\
(0.180)^{* * *}\end{array}$ & & \\
\hline Rich Household & & $\begin{array}{l}-0.194 \\
(0.213)\end{array}$ & & \\
\hline Economic Reason & & & $\begin{array}{l}0.027 \\
(0.139)\end{array}$ & \\
\hline Civil Servant & & & & $\begin{array}{c}0.096 \\
(0.233)\end{array}$ \\
\hline Business Sales & & & & $\begin{array}{l}-0.040 \\
(0.150)\end{array}$ \\
\hline Craft and Trade Workers & & & & $\begin{array}{l}-0.179 \\
(0.228)\end{array}$ \\
\hline Elementary Occupation & & & & $\begin{array}{c}0.171 \\
(0.185)\end{array}$ \\
\hline Other Sources of Income & & & & $\begin{array}{l}-0.193 \\
(0.355)\end{array}$ \\
\hline Constant & $\begin{array}{c}0.265 \\
(0.638)\end{array}$ & $\begin{array}{c}-0.001 \\
(0.603)\end{array}$ & $\begin{array}{c}0.195 \\
(0.636)\end{array}$ & $\begin{array}{c}0.280 \\
(0.638)\end{array}$ \\
\hline Country Variance & $\begin{array}{c}0.712 \\
(0.516)\end{array}$ & $\begin{array}{c}0.575 \\
(0.410)\end{array}$ & $\begin{array}{c}0.696 \\
(0.492)\end{array}$ & $\begin{array}{c}0.710 \\
(0.504)\end{array}$ \\
\hline District Variance & $\begin{array}{c}0.188 \\
(0.083)\end{array}$ & $\begin{array}{c}0.146 \\
(0.085)\end{array}$ & $\begin{array}{c}0.188 \\
(0.083)\end{array}$ & $\begin{array}{c}0.193 \\
(0.085)\end{array}$ \\
\hline Observations & 1,804 & 1,316 & 1,812 & 1,781 \\
\hline Number of Groups & 5 & 5 & 5 & 5 \\
\hline Log Likelihood & $-1,069.344$ & -762.116 & $-1,076.511$ & $-1,061.226$ \\
\hline Wald $\chi^{2}$ & $20.96 * *$ & $21.84 * * *$ & $16.97 * *$ & $20.13^{*}$ \\
\hline
\end{tabular}

Table entries are coefficients from multilevel logistic regression models with country level and district level random effects; standard errors in parentheses.

*** significant at $1 \% ; * *$ significant at $5 \% ; *$ significant at $10 \%$. 
Table A7. General Conflict Perception Multilevel Logistic Regression Models - Interaction with Polity

\begin{tabular}{|c|c|c|c|c|}
\hline & $\begin{array}{c}\text { Model } 17 \\
\text { (Conflict } \\
\text { Perception) }\end{array}$ & $\begin{array}{c}\text { Model } 18 \\
\text { (Conflict } \\
\text { Perception) }\end{array}$ & $\begin{array}{c}\text { Model } 19 \\
\text { (Conflict } \\
\text { Perception) }\end{array}$ & $\begin{array}{c}\text { Model } 20 \\
\text { (Conflict } \\
\text { Perception) } \\
\end{array}$ \\
\hline Sudden, Short-Term Events & $\begin{array}{c}0.028 \\
(0.200)\end{array}$ & $\begin{array}{l}-0.087 \\
(0.262)\end{array}$ & $\begin{array}{c}0.031 \\
(0.199)\end{array}$ & $\begin{array}{l}-0.020 \\
(0.202)\end{array}$ \\
\hline Gradual, Long-Term Events & $\begin{array}{c}0.535 \\
(0.141)^{* * *}\end{array}$ & $\begin{array}{c}0.483 \\
(0.193)^{* *}\end{array}$ & $\begin{array}{c}0.538 \\
(0.140)^{* * *}\end{array}$ & $\begin{array}{c}0.545 \\
(0.142)^{* * *}\end{array}$ \\
\hline Polity (Democracy) & $\begin{array}{l}-0.042 \\
(0.065)\end{array}$ & $\begin{array}{c}-0.088 \\
(0.063)\end{array}$ & $\begin{array}{c}-0.042 \\
(0.065)\end{array}$ & $\begin{array}{l}-0.046 \\
(0.065)\end{array}$ \\
\hline Sudden Events * Polity & $\begin{array}{c}0.013 \\
(0.028)\end{array}$ & $\begin{array}{c}0.021 \\
(0.035)\end{array}$ & $\begin{array}{c}0.012 \\
(0.027)\end{array}$ & $\begin{array}{c}0.016 \\
(0.028)\end{array}$ \\
\hline Gradual Events * Polity & $\begin{array}{c}-0.032 \\
(0.021)\end{array}$ & $\begin{array}{l}-0.023 \\
(0.028)\end{array}$ & $\begin{array}{c}-0.034 \\
(0.021)\end{array}$ & $\begin{array}{l}-0.034 \\
(0.021)\end{array}$ \\
\hline Female & $\begin{array}{c}0.089 \\
(0.112)\end{array}$ & $\begin{array}{c}0.111 \\
(0.135)\end{array}$ & $\begin{array}{c}0.085 \\
(0.110)\end{array}$ & $\begin{array}{c}0.089 \\
(0.111)\end{array}$ \\
\hline Age & $\begin{array}{l}-0.003 \\
(0.006)\end{array}$ & $\begin{array}{l}-0.005 \\
(0.007)\end{array}$ & $\begin{array}{l}-0.007 \\
(0.006)\end{array}$ & $\begin{array}{l}-0.009 \\
(0.006)\end{array}$ \\
\hline Household Member Migrated & $\begin{array}{l}-0.151 \\
(0.111)\end{array}$ & $\begin{array}{l}-0.036 \\
(0.133)\end{array}$ & $\begin{array}{l}-0.134 \\
(0.110)\end{array}$ & $\begin{array}{l}-0.135 \\
(0.112)\end{array}$ \\
\hline No Education & $\begin{array}{l}-0.153 \\
(0.292)\end{array}$ & & & \\
\hline Primary Education & $\begin{array}{c}-0.248 \\
(0.199)\end{array}$ & & & \\
\hline Secondary Education & $\begin{array}{c}-0.253 \\
(0.130)^{*}\end{array}$ & & & \\
\hline Poor Household & & $\begin{array}{c}0.576 \\
(0.181)^{* * *}\end{array}$ & & \\
\hline Rich Household & & $\begin{array}{l}-0.198 \\
(0.214)\end{array}$ & & \\
\hline Economic Reason & & & $\begin{array}{c}0.043 \\
(0.139)\end{array}$ & \\
\hline Civil Servant & & & & $\begin{array}{c}0.059 \\
(0.234)\end{array}$ \\
\hline Business Sales & & & & $\begin{array}{l}-0.054 \\
(0.151)\end{array}$ \\
\hline Craft and Trade Workers & & & & $\begin{array}{l}-0.196 \\
(0.228)\end{array}$ \\
\hline Elementary Occupation & & & & $\begin{array}{c}0.158 \\
(0.185)\end{array}$ \\
\hline Other Sources of Income & & & & $\begin{array}{l}-0.208 \\
(0.355)\end{array}$ \\
\hline Constant & $\begin{array}{c}0.217 \\
(0.476)\end{array}$ & $\begin{array}{c}0.001 \\
(0.486)\end{array}$ & $\begin{array}{c}0.142 \\
(0.478)\end{array}$ & $\begin{array}{c}0.262 \\
(0.477)\end{array}$ \\
\hline Country Variance & $\begin{array}{c}0.631 \\
(0.473)\end{array}$ & $\begin{array}{c}0.485 \\
(0.366)\end{array}$ & $\begin{array}{c}0.619 \\
(0.451)\end{array}$ & $\begin{array}{c}0.619 \\
(0.455)\end{array}$ \\
\hline District Variance & $\begin{array}{c}0.198 \\
(0.086)\end{array}$ & $\begin{array}{c}0.154 \\
(0.089)\end{array}$ & $\begin{array}{c}0.198 \\
(0.086)\end{array}$ & $\begin{array}{c}0.203 \\
(0.088)\end{array}$ \\
\hline Observations & 1,804 & 1,316 & 1,812 & 1,781 \\
\hline Number of Groups & 5 & 5 & 5 & 5 \\
\hline Log Likelihood & $-1,067.967$ & -761.540 & $-1,075.031$ & $-1,059.665$ \\
\hline Wald $\chi^{2}$ & $23.63 * *$ & $23.09 * *$ & $19.92 * *$ & $23.24 * *$ \\
\hline
\end{tabular}

Table entries are coefficients from multilevel logistic regression models with country level and district level random effects; standard errors in parentheses.

*** significant at $1 \% ; * *$ significant at $5 \% ; *$ significant at $10 \%$. 
Table A8. General Conflict Perception Multilevel Logistic Regression Models - Interaction with GDP per capita

\begin{tabular}{|c|c|c|c|c|}
\hline & $\begin{array}{c}\text { Model } 21 \\
\text { (Conflict } \\
\text { Perception) } \\
\end{array}$ & $\begin{array}{c}\text { Model } 22 \\
\text { (Conflict } \\
\text { Perception) }\end{array}$ & $\begin{array}{c}\text { Model } 23 \\
\text { (Conflict } \\
\text { Perception) } \\
\end{array}$ & $\begin{array}{c}\text { Model } 24 \\
\text { (Conflict } \\
\text { Perception) }\end{array}$ \\
\hline Sudden, Short-Term Events & $\begin{array}{c}0.031 \\
(0.251)\end{array}$ & $\begin{array}{l}-0.041 \\
(0.271)\end{array}$ & $\begin{array}{c}0.034 \\
(0.250)\end{array}$ & $\begin{array}{l}-0.031 \\
(0.253)\end{array}$ \\
\hline Gradual, Long-Term Events & $\begin{array}{c}0.745 \\
(0.219)^{* * *}\end{array}$ & $\begin{array}{c}0.765 \\
(0.247)^{* * *}\end{array}$ & $\begin{array}{c}0.750 \\
(0.217)^{* * *}\end{array}$ & $\begin{array}{c}0.766 \\
(0.221)^{* * *}\end{array}$ \\
\hline GDP per capita & $\begin{array}{l}-0.001 \\
(0.001)\end{array}$ & $\begin{array}{l}-0.001 \\
(0.001)\end{array}$ & $\begin{array}{l}-0.001 \\
(0.001)\end{array}$ & $\begin{array}{l}-0.001 \\
(0.001)\end{array}$ \\
\hline Sudden Events * GDP per capita & $\begin{array}{c}0.001 \\
(0.001)\end{array}$ & $\begin{array}{c}0.001 \\
(0.001)\end{array}$ & $\begin{array}{c}0.001 \\
(0.001)\end{array}$ & $\begin{array}{c}0.001 \\
(0.001)\end{array}$ \\
\hline Gradual Events * GDP per capita & $\begin{array}{l}-0.001 \\
(0.001)\end{array}$ & $\begin{array}{c}-0.001 \\
(0.000)^{*}\end{array}$ & $\begin{array}{l}-0.001 \\
(0.001)\end{array}$ & $\begin{array}{l}-0.001 \\
(0.001)\end{array}$ \\
\hline Female & $\begin{array}{c}0.095 \\
(0.111)\end{array}$ & $\begin{array}{c}0.118 \\
(0.135)\end{array}$ & $\begin{array}{c}0.090 \\
(0.110)\end{array}$ & $\begin{array}{c}0.093 \\
(0.111)\end{array}$ \\
\hline Age & $\begin{array}{l}-0.003 \\
(0.006)\end{array}$ & $\begin{array}{l}-0.004 \\
(0.007)\end{array}$ & $\begin{array}{l}-0.007 \\
(0.006)\end{array}$ & $\begin{array}{l}-0.008 \\
(0.006)\end{array}$ \\
\hline Household Member Migrated & $\begin{array}{l}-0.137 \\
(0.111)\end{array}$ & $\begin{array}{l}-0.018 \\
(0.133)\end{array}$ & $\begin{array}{l}-0.119 \\
(0.110)\end{array}$ & $\begin{array}{l}-0.122 \\
(0.112)\end{array}$ \\
\hline No Education & $\begin{array}{l}-0.167 \\
(0.292)\end{array}$ & & & \\
\hline Primary Education & $\begin{array}{l}-0.257 \\
(0.198)\end{array}$ & & & \\
\hline Secondary Education & $\begin{array}{l}-0.250 \\
(0.130)^{*}\end{array}$ & & & \\
\hline Poor Household & & $\begin{array}{c}0.577 \\
(0.178)^{* * *}\end{array}$ & & \\
\hline Rich Household & & $\begin{array}{l}-0.204 \\
(0.213)\end{array}$ & & \\
\hline Economic Reason & & & $\begin{array}{c}0.029 \\
(0.139)\end{array}$ & \\
\hline Civil Servant & & & & $\begin{array}{c}0.080 \\
(0.233)\end{array}$ \\
\hline Business Sales & & & & $\begin{array}{l}-0.042 \\
(0.150)\end{array}$ \\
\hline Craft and Trade Workers & & & & $\begin{array}{l}-0.191 \\
(0.227)\end{array}$ \\
\hline Elementary Occupation & & & & $\begin{array}{c}0.160 \\
(0.186)\end{array}$ \\
\hline Other Sources of Income & & & & $\begin{array}{l}-0.229 \\
(0.357)\end{array}$ \\
\hline Constant & $\begin{array}{c}0.241 \\
(0.627)\end{array}$ & $\begin{array}{l}-0.033 \\
(0.637)\end{array}$ & $\begin{array}{c}0.172 \\
(0.626)\end{array}$ & $\begin{array}{c}0.281 \\
(0.624)\end{array}$ \\
\hline Country Variance & $\begin{array}{c}0.645 \\
(0.474)\end{array}$ & $\begin{array}{c}0.614 \\
(0.431)\end{array}$ & $\begin{array}{c}0.631 \\
(0.452)\end{array}$ & $\begin{array}{c}0.632 \\
(0.456)\end{array}$ \\
\hline District Variance & $\begin{array}{c}0.177 \\
(0.079)\end{array}$ & $\begin{array}{c}0.120 \\
(0.077)\end{array}$ & $\begin{array}{c}0.175 \\
(0.078)\end{array}$ & $\begin{array}{c}0.179 \\
(0.080)\end{array}$ \\
\hline Observations & 1,804 & 1,316 & 1,812 & 1,781 \\
\hline Number of Groups & 5 & 5 & 5 & 5 \\
\hline Log Likelihood & $-1,068.122$ & -760.359 & $-1,075.251$ & $-1,059.813$ \\
\hline Wald $\chi^{2}$ & $23.49 * *$ & $25.45^{* * *}$ & $19.61 * *$ & $23.06^{* *}$ \\
\hline
\end{tabular}

Table entries are coefficients from multilevel logistic regression models with country level and district level random effects; standard errors in parentheses.

$* * *$ significant at $1 \% ; * *$ significant at $5 \% ; *$ significant at $10 \%$. 
Table A9. General Conflict Perception Logistic Regression Models with Country Fixed Effects

\begin{tabular}{|c|c|}
\hline & $\begin{array}{c}\text { Model } 25 \\
\text { (Conflict Perception) }\end{array}$ \\
\hline Sudden, Short-Term Events & $\begin{array}{c}0.205 \\
(0.157)\end{array}$ \\
\hline Gradual, Long-Term Events & $\begin{array}{c}0.286 \\
(0.127)^{* *}\end{array}$ \\
\hline Female & $\begin{array}{c}0.082 \\
(0.108)\end{array}$ \\
\hline Age & $\begin{array}{c}0.003 \\
(0.006)\end{array}$ \\
\hline Household Member Migrated & $\begin{array}{c}-0.184 \\
(0.106)^{*}\end{array}$ \\
\hline No Education & $\begin{array}{l}-0.277 \\
(0.287)\end{array}$ \\
\hline Primary Education & $\begin{array}{l}-0.288 \\
(0.191)\end{array}$ \\
\hline Secondary Education & $\begin{array}{l}-0.244 \\
(0.125)^{*}\end{array}$ \\
\hline Peru & $\begin{array}{c}0.833 \\
(0.182)^{* * *}\end{array}$ \\
\hline Uganda & $\begin{array}{c}3.081 \\
(0.301)^{* * *}\end{array}$ \\
\hline Cambodia & $\begin{array}{c}1.024 \\
(0.199)^{* * *}\end{array}$ \\
\hline Vietnam & $\begin{array}{c}0.467 \\
(0.172)^{* * *}\end{array}$ \\
\hline Constant & $\begin{array}{c}-1.106 \\
(0.275)^{* * *}\end{array}$ \\
\hline Observations & 1,804 \\
\hline Log Likelihood & $-1,077.070$ \\
\hline Likelihood Ratio $\chi^{2}$ & $346.42 * * *$ \\
\hline
\end{tabular}

Table entries are coefficients from logistic regression models with country fixed effects (Nicaragua as baseline); standard errors in parentheses.

$* * *$ significant at $1 \% ; * *$ significant at $5 \% ; *$ significant at $10 \%$. 
Table A10. Overview of Surveys

\begin{tabular}{|c|c|c|c|c|c|}
\hline & Vietnam & Uganda & Cambodia & Nicaragua & Peru \\
\hline $\begin{array}{c}\text { Non Migrants: } \\
\text { Subnational } \\
\text { Locations and } \\
\text { Type of } \\
\text { Environmental } \\
\text { Problems }\end{array}$ & $\begin{array}{c}\text { Ba Tri } \\
\text { (salinity), } \\
\text { Chau Phu } \\
\text { (flood), } \\
\text { Giao Thuy } \\
\text { (cyclone), and } \\
\text { Ninh Hai } \\
\text { (drought) }\end{array}$ & $\begin{array}{c}\text { Kotido and } \\
\text { Moroto } \\
\text { (drought, heavy } \\
\text { rain/flood) }\end{array}$ & $\begin{array}{l}\text { Cheung Prey, } \\
\text { Kang Meas, } \\
\text { Koh Sotin, and } \\
\text { Krouch Chhma } \\
\text { (storm/flood) } \\
\text { Khsach kandal, } \\
\text { Koaoh Thum, } \\
\text { and Lvea Aem } \\
\text { S'ang } \\
\text { (flood/drought) }\end{array}$ & $\begin{array}{l}\text { Managua, } \\
\text { Chinandega, } \\
\text { and Leon } \\
\text { (drought) } \\
\text { R.A.A.N and } \\
\text { R.A.A.S } \\
\text { (storms) }\end{array}$ & $\begin{array}{c}\text { Cusco (flood, } \\
\text { cold weather), } \\
\text { Puno (drought), } \\
\text { Piura } \\
\text { (drought/flood), } \\
\text { Arequipa } \\
\text { (flood), } \\
\text { Lima (drought) }\end{array}$ \\
\hline $\begin{array}{c}\text { Migrants: } \\
\text { Regional and } \\
\text { Capital Cities }\end{array}$ & $\begin{array}{l}\text { Hanoi and } \\
\text { Ho Chi Minh } \\
\text { city }\end{array}$ & $\begin{array}{l}\text { Kampala, } \\
\text { Kotido, and } \\
\text { Mbale }\end{array}$ & $\begin{array}{l}\text { Phnom Penh, } \\
\text { and } \\
\text { Kampong, } \\
\text { Cham }\end{array}$ & $\begin{array}{l}\text { Managua, Leon, } \\
\text { and Chinandega }\end{array}$ & $\begin{array}{c}\text { Cusco, } \\
\text { Puno, } \\
\text { Piura, } \\
\text { Arequipa, and } \\
\text { Lima }\end{array}$ \\
\hline $\begin{array}{l}\text { Political } \\
\text { System }\end{array}$ & $\begin{array}{c}\text { Autocracy } \\
\text { Polity IV: -7 }\end{array}$ & $\begin{array}{c}\text { Anocracy } \\
\text { Polity IV:-1 }\end{array}$ & $\begin{array}{c}\text { Anocracy } \\
\text { Polity IV: } 2\end{array}$ & $\begin{array}{l}\text { Democracy } \\
\text { Polity IV: } 9\end{array}$ & $\begin{array}{l}\text { Democracy } \\
\text { Polity IV: } 9\end{array}$ \\
\hline $\begin{array}{l}\text { Income }-G D P \\
\text { per capita } 2012\end{array}$ & 1,755 USD & 653 USD & 946 USD & 6,424 USD & 1,777 USD \\
\hline $\begin{array}{c}\text { Number of } \\
\text { Participants } \\
\text { (50 percent } \\
\text { Migrants) }\end{array}$ & 1,200 & 672 & 600 & 600 & 617 \\
\hline Survey Period & Sept-Oct 2013 & Sept-Oct 2013 & Jan-Feb 2014 & Mar-Apr 2014 & Jul-Aug 2014 \\
\hline
\end{tabular}


Figure A1. Nicaragua with Locations of Interviews

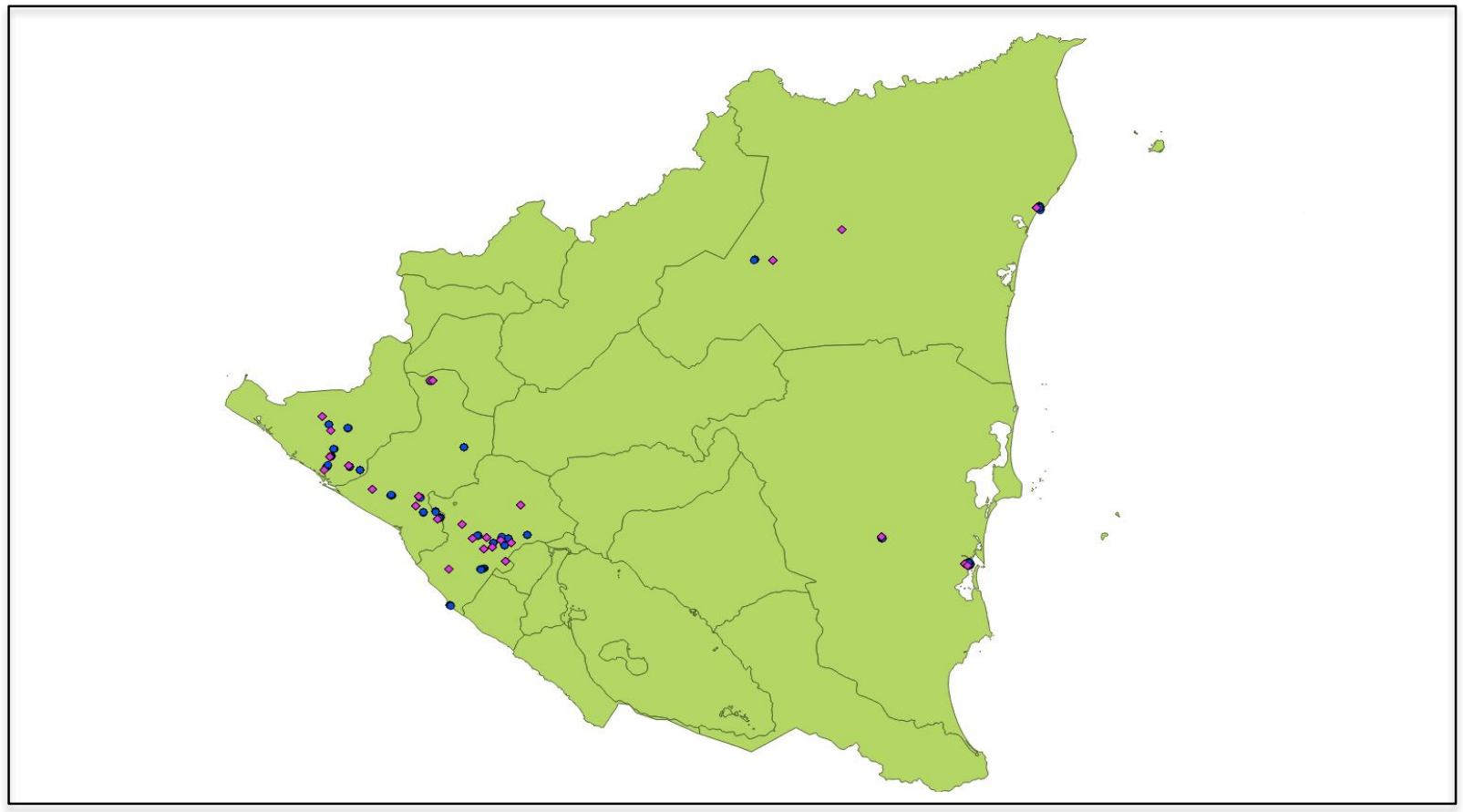

Graph shows map of Nicaragua. Blue circles pertain to non-migrants, while purple diamonds stand for interview locations of migrants.

Figure A2. Peru with Locations of Interviews

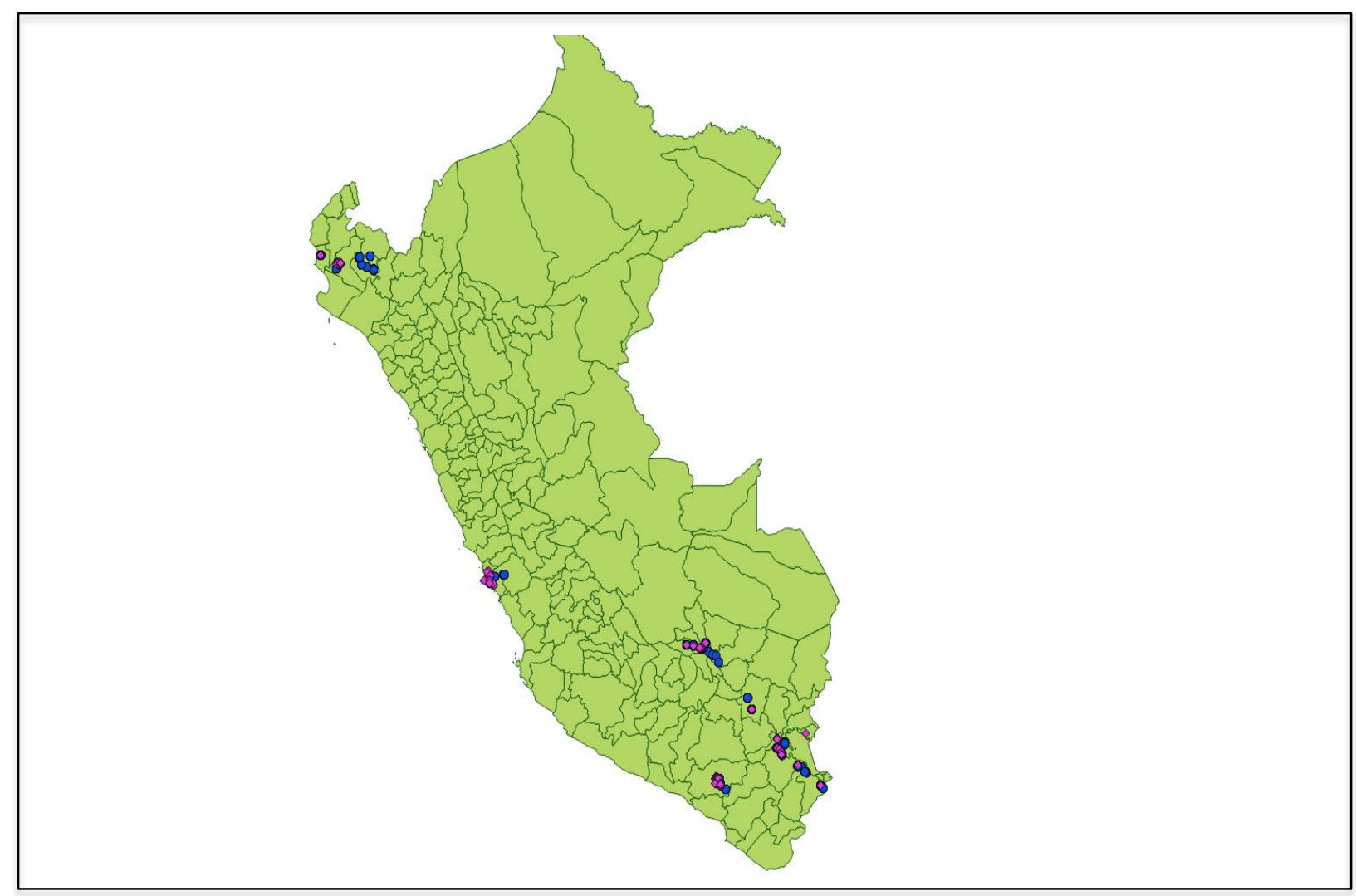

Graph shows map of Peru. Blue circles pertain to non-migrants, while purple diamonds stand for interview locations of migrants. 
Figure A3. Cambodia with Locations of Interviews

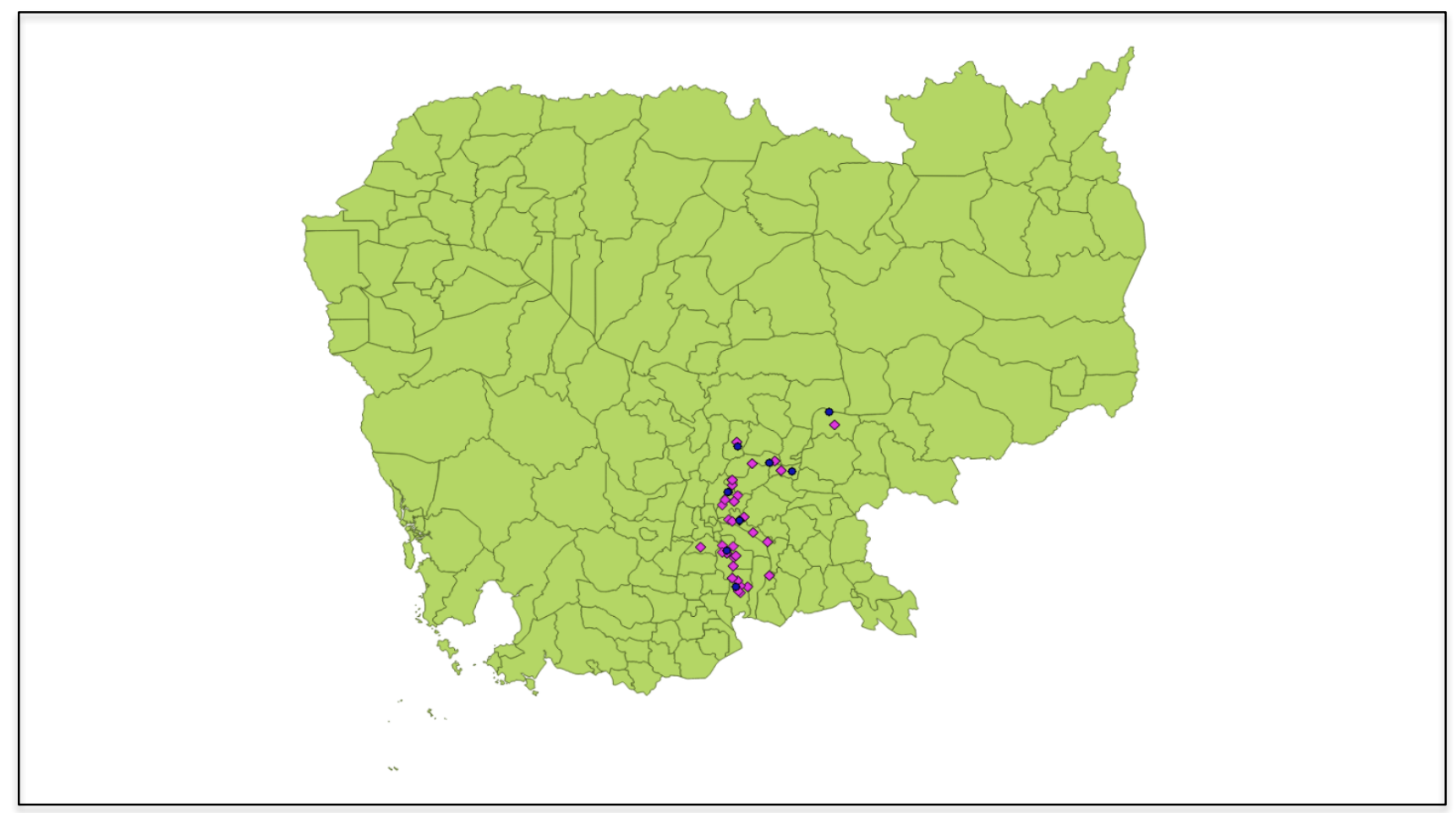

Graph shows map of Cambodia. Blue circles pertain to non-migrants, while purple diamonds stand for interview locations of migrants.

Figure A4. Uganda with Locations of Interviews

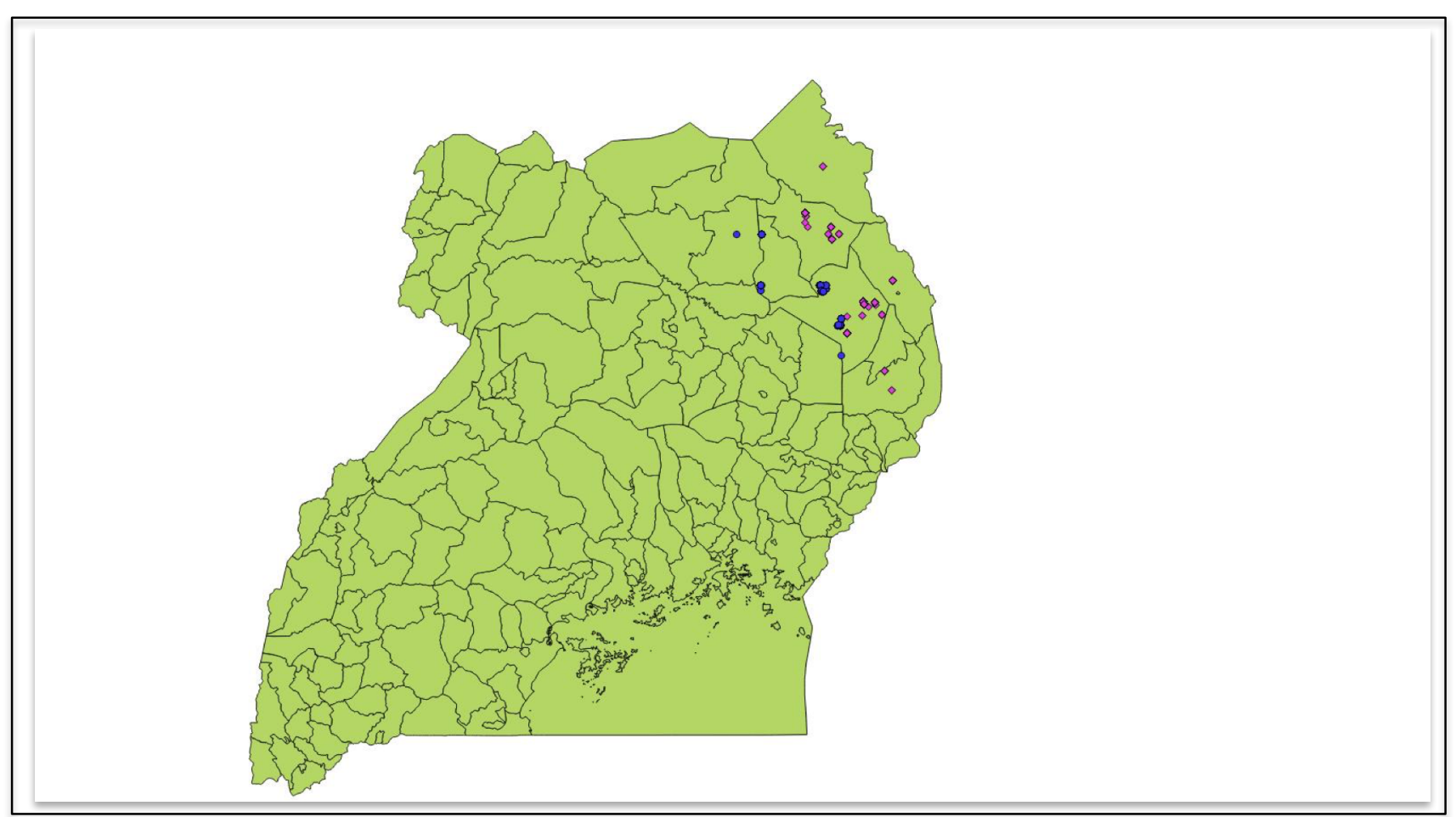

Graph shows map of Uganda. Blue circles pertain to non-migrants, while purple diamonds stand for interview locations of migrants. 
Figure A5. Vietnam with Locations of Interviews

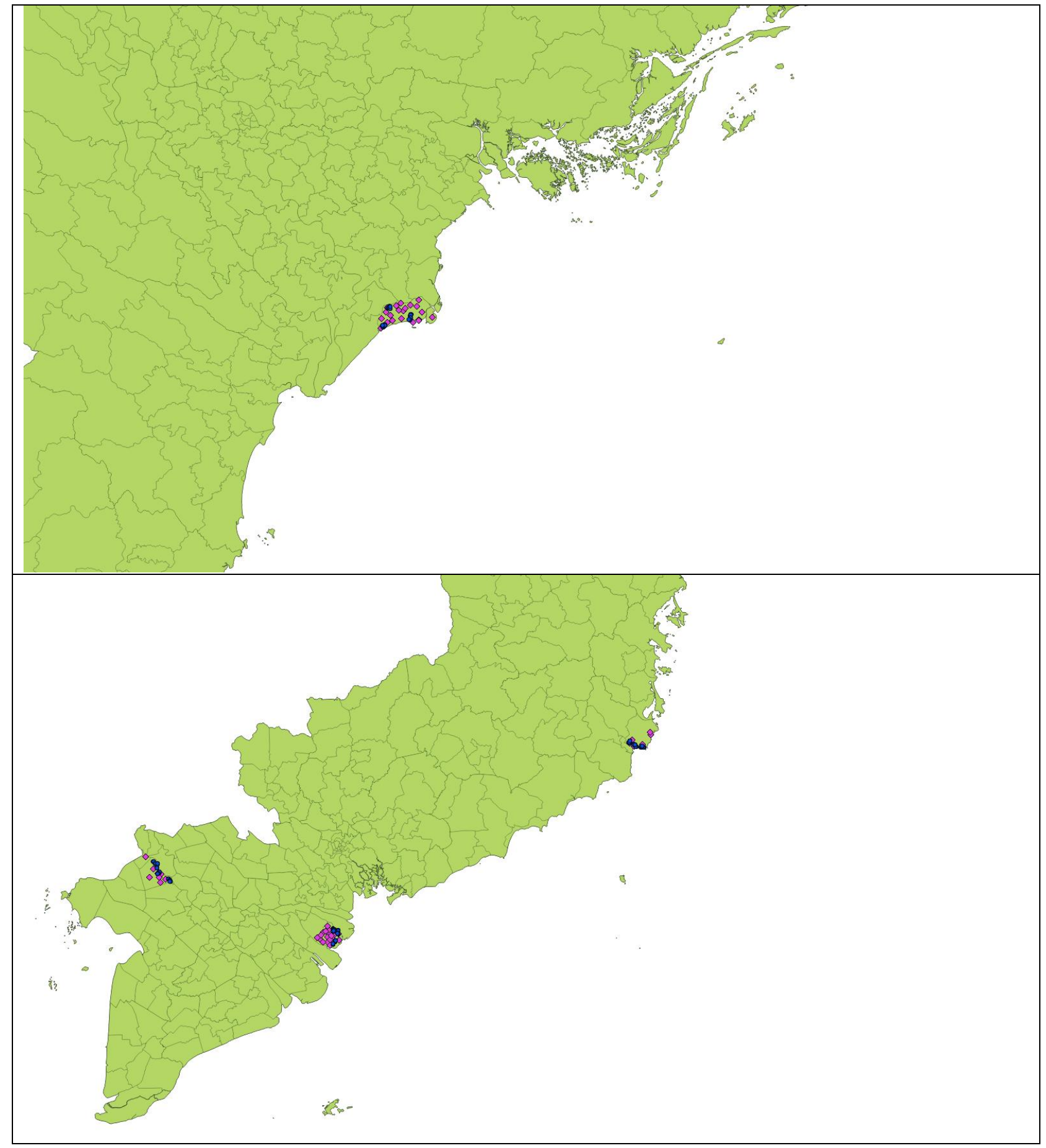

Graphs show map of Vietnam (upper panel: North; lower panel: South). Blue circles pertain to non-migrants, while purple diamonds stand for interview locations of migrants. 


\section{Questionnaire}

Interview ID

Date:

Interviewer ID

Location: [to be filled out prior to interview]

Coordinates:

Commune/Village/Town:

District:

Province:
Current Weather [observed]:

Number of households (HH) in village/town:

Respondent: [based on observation]

Household Status [scale determined before start of interview]

1. Very poor

2. Poor

3. Average

4. Above average

5. Wealthy

99. N/A [Circle if interview not conducted in respondent home]

Sex of Respondent

1. Female 2. Male

\section{Interview Schedule}

How long have you lived in this location?

1. Since birth

2. [years]

99. Don't Know/Refused to Answer

Where did you come from?

Commune/Village: District Province

Were you born there?

1. Yes

2. No

99. Don't Know/Refused to Answer

How long were you in that previous location for? 99. Don't Know/Refused to Answer years

What is the highest level of formal education you have attended?

[Ask for specific number of years completed]

1. No formal education

2. Primary school Years completed 
3. Secondary Years completed

4. Technical Years completed

5. Post-Secondary Years completed

6. Other

99. Don't know/Refused to Answer

Could you tell us your age?

[If does not know or refuses to respond, interviewer to guess]

Which ethnic group do you belong to?

99. Don't know/Refused to Answer

I will read you a list of sources of income. Could you tell us which are your (household) main source(s) of income? (Non-migrant) - I will read you a list of sources of income. Could you tell us which were your (household) main source(s) of income in your former location? (Migrant)

(Circle all mentioned. If more than one was mentioned, ask to rank them in order of importance (from 1-5, 1 the most important) (Insert number in spaces provided in question BELOW)

1. Agriculture/Farm /animal /fishing income

2._ Proceeds as shop/business owner

3._ Proceeds markets sales (non-farm)

4._ Civil servant salary

5._ Salary from industry (firm, factory, corporation)

6. Salary from labor (handicrafts, construction)

7. Day Labor-Temporary

8._ Artisanal Mining

9. Remittances

10. Professional

$11 . \quad$ Other

99. Don't Know /Refused to Answer

From your perspective, can you describe the main weather event(s) that have happened here during the last 5 years? (Non-migrant) - From your perspective, can you describe the main weather event(s) that occurred during the past five years before you left your previous residence? (Migrant)

IIf respondent is unable to answer freely, read the list. For each reported event follow up with questions in the following table]. [Circle all that apply] Show Card

1. Heavy Rains/Floods [please circle]

2. Salinity

3. Snow/Hail [please circle]

4. Drought/Desertification [please circle]

5. Storm/Cyclone/Typhoon [please circle]

6. Landslide/Mudslide/Avalanche [please circle]

7. Other

8. None

99. Don't Know/Refused to Answer 


\begin{tabular}{|c|c|c|c|c|c|c|c|}
\hline $\begin{array}{l}\text { Circle events } \\
\text { reported in } \\
\text { previous } \\
\text { question }\end{array}$ & $\begin{array}{l}\text { 1. Heavy } \\
\text { Rain/Flood }\end{array}$ & 2. Salinity & 3. Snow/Hail & $\begin{array}{l}\text { 4. Drought/ } \\
\text { Desertificatio } \\
\text { n }\end{array}$ & $\begin{array}{l}\text { 5. Cyclone/ } \\
\text { Typhoon/ } \\
\text { Storm }\end{array}$ & $\begin{array}{l}\text { 6. Landslide/ } \\
\text { Mudslide/ } \\
\text { Avalanche/ }\end{array}$ & 7. Other \\
\hline \multirow{3}{*}{$\begin{array}{l}\text { [For short } \\
\text { term events] } \\
\text { When did this } \\
\text { event last } \\
\text { occur? } \\
\text { [Or for } \\
\text { progressive } \\
\text { environmenta } \\
\text { l events] } \\
\text { When did } \\
\text { this event } \\
\text { begin? }\end{array}$} & & & & & & & \\
\hline & $\overline{\text { Month }}$ & $\overline{\text { Month }}$ & $\overline{\text { Month }}$ & $\overline{\text { Month }}$ & $\overline{\text { Month }}$ & Month & $\overline{\text { Month }}$ \\
\hline & $\begin{array}{l}\text { Year } \\
\text { 99. DK/RA }\end{array}$ & $\begin{array}{l}\text { Year } \\
\text { 99. DK/RA }\end{array}$ & $\begin{array}{l}\text { Year } \\
\text { 99. DK/RA }\end{array}$ & $\begin{array}{l}\text { Year } \\
\text { 99. DK/RA }\end{array}$ & $\begin{array}{l}\text { Year } \\
\text { 99. DK/RA }\end{array}$ & $\begin{array}{l}\text { Year } \\
\text { 99. DK/RA }\end{array}$ & $\begin{array}{l}\text { Year } \\
\text { 99. DK/RA }\end{array}$ \\
\hline $\begin{array}{l}\text { How long did } \\
\text { this event } \\
\text { last? }\end{array}$ & $\begin{array}{l}\text { 1. days } \\
\text { 2. weeks } \\
\text { 3. months } \\
\text { 4. years } \\
\text { 99. DK/RA }\end{array}$ & $\begin{array}{l}\text { 1. days } \\
\text { 2. weeks } \\
\text { 3. months } \\
\text { 4. years } \\
\text { 99. DK/RA }\end{array}$ & $\begin{array}{l}\text { 1. days } \\
\text { 2. weeks } \\
\text { 3. months } \\
\text { 4. years } \\
\text { 99. DK/RA }\end{array}$ & $\begin{array}{l}\text { 1. days } \\
\text { 2. weeks } \\
\text { 3. months } \\
\text { 4. years } \\
\text { 99. DK/RA }\end{array}$ & $\begin{array}{l}\text { 1. days } \\
\text { 2. weeks } \\
\text { 3. months } \\
\text { 4. years } \\
\text { 99. DK/RA }\end{array}$ & $\begin{array}{l}\text { 1. days } \\
\text { 2. weeks } \\
\text { 3. months } \\
\text { 4. years } \\
\text { 99. DK/RA }\end{array}$ & $\begin{array}{l}\text { 1. days } \\
\text { 2. weeks } \\
\text { 3. months } \\
\text { 4. years } \\
\text { 99. DK/RA }\end{array}$ \\
\hline
\end{tabular}

Have you ever thought about migrating? If yes, then ask: What was/were the reason(s)? (Nonmigrant) - I would like to ask you all the reason(s) why you decided to move from your former location. (Migrant)

[Allow respondents to answer without reading list and circle all responses in "Unprompted Column". Then follow up by reading list/Show Card. Additional responses should be circled in "Prompted Column"]

Social reasons: for example, Marriage; There are family/relatives in the new location; I was facing discrimination; There was insecurity (physical \&/or sexual); To seek health care (inadequate health care in area); To seek schooling (e.g. no school in area); Other

Economic reasons: for example, Not enough income from livelihood sources; Unreliable harvest; No land available for farming/agriculture; Crop failure; Unemployment in that location; Job opportunity in new place; Higher income in new place; Other

Environmental reasons: for example, Water shortage/Drought [1 event]; Repeated droughts /Long Term salinity; Too much water; Short term events such as flood, storm, landslide, cyclone: Single event or Repeated Event; Other

Political reasons: for example, There was conflict; To seek political freedom; Government provided incentives for me to go; Government forced me to move; Other

Of all the reasons you mentioned, could you please rank the top three most important factors? [Write number of code from above reason in first, second and third place below, with number 1 as the most important]

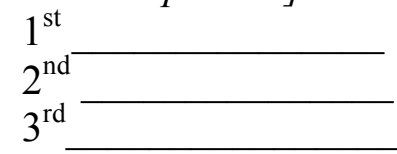

99. Don’t Know/Refused to Answer 
Up until now, have members of your household left temporarily or permanently for other places or even abroad? (Non-migrant) -Up until now, have other members of your household in your previous location left temporarily or permanently for other places, or even abroad? [Excluding respondent](Migrant)

1. Yes

2. No

99. Don't Know/Refused to Answer

Do you know of anyone who left after having experienced the same event(s) (drought/desertification/flood/cyclone/etc)? [Not from the same HH] (Non-migrant) - Do you know anyone else who left from your previous location around the same time you did? [Other than you] (Migrant)

1. Yes

2. No

99. Don't Know/Refused to Answer

Where did they go? [List all locations mentioned]

Would you be willing to provide us with the name and contact information for these people so that we may ask a similar set of questions? 


\section{References}

Adger, Neil. 2003. Social Capital, Collective Action, and Adaptation to Climate Change. Economic Geography 79(4): 387-404.

Agnew, Robert. 2012. Dire forecast: A Theoretical Model of the Impact of Climate Change on Crime. Theoretical Criminology 16(1): 21-42.

Aldwin, Carolyn. 1991. Does Age Affect the Stress and Coping Process? Implications of Age Differences in Perceived Control. Journal of Gerontology 46(4): 174-180.

Anderson, Craig A. 2012. Heat and Violence. Current Directions in Psychological Science 10(1): 133-138.

Anderson, Craig A., and Matt Delisi. 2011. Implications of Global Climate Change for Violence in Developed and Developing Countries. In: Joseph P. Forgas, Arie W. Krugianski, and Kipling D. Williams (eds), The Psychology of Social Conflict and Aggression. Psychology Press, New York, pp. 249-265.

Anderson, Craig A., Kathryn B. Anderson, Nancy Dorr, Kristina M. DeNeve, and Mindy Flanagan. 2000. Temperature and Aggression. Advances in Experimental Social Psychology 32(1): 63-133.

Armstrong, Paula S., and Michael D. Schulman. 1990. Financial Strain and Depression Among Farm Operators: The Role of Perceived Economic Hardship and Personal Control. Rural Sociology 55(4): 475-493.

Bandura, Albert. 1973. Aggression: A Social Leaning Analysis. Englewood Cliffs, NJ: Prentice Hall.

Barrios, Salvador, Luisito Bertinelli, and Eric Strobl. 2010. Trends in Rainfall and Economic Growth in Africa: A Neglected Cause of the African Growth Tragedy. Review of Economics and Statistics 92(2): 350-366.

Barnett, Jon, and Neil Adger. 2007. Climate Change, Human Security, and Violence. Political Geography 26(6): 639-655. 
Berkowitz, Leonard. 1993. Pain and Aggression: Some Findings and Implications. Motivation and Emotion 17(3): 277-293.

Berkowitz, Leonard. 1989. Frustration-Aggression Hypothesis: Examination and Reformulation. Psychological Bulletin 106(1): 59-73.

Bernauer, Thomas, Tobias Böhmelt, and Vally Koubi. 2012. Environmental Changes and Violent Conflict. Environmental Research Letters 7(1): 015601.

Berry, John W. 2006. Stress perspectives on acculturation. In: David L. Sam, John W. Berry (ed), The Cambridge Handbook of Acculturation Psychology. Cambridge: Cambridge University Press, pp. 43-57.

Berry, John W. 1997. Immigration, Acculturation, and Adaptation. Applied Psychology: An International Review 46(1): 5-68.

Bhavnani, Rikhil, and Bethany Lacina. 2013. The Effects of Weather-Induced Migration on Sons of the Soil Violence in India. Typescript.

Biermann, Frank, and Klaus Dingwerth. 2004. Global Environmental Change and the Nation State. Global Environmental Politics 4: 1-22.

Black, Richard, W. Neil Adger, Nigel W. Arnell, Stefan Dercon, Andrew Geddes, and David Thomas. 2011. The Effect of Environmental Change on Human Migration. Global Environmental Change 21(1): 3-11.

Black, Richard, Nigel W. Arnell, W. Neil Adger, David Thomas, and Andrew Geddes. 2013. Migration, Immobility, and Displacement Outcomes of Extreme Events in Nature and Society. Environmental Science and Policy 27(1): 32-43.

Blair, Graeme, C. Christine Fair, Neil Malhotra, and Jacob N. Shapiro. 2013. Poverty and Support for Militant Politics: Evidence from Pakistan. American Journal of Political Science 57(1): 30-48.

Bohnet, Heidrun, Fabien Cottier, and Simon Hug. 2014. Conflict versus Disaster-Induced Migration. Similar or Distinct Implications for Security? Typescript. 
Bove, Vincenzo, and Tobias Böhmelt. 2016. Does Immigration Induce Terrorism? Journal of Politics 78(2): 572-588.

Brett Rachel, and Irma Specht. 2004. Young Soldiers: Why They Choose to Fight. Boulder, CO: Lynne Rienner.

Biermann, Frank, and Klaus Dingwerth. 2004. Global Environmental Change and the Nation State. Global Environmental Politics 4: 1-22.

Buhaug, Halvard. 2016. Climate Change and Conflict: Taking Stock. Peace Economics, Peace Science and Public Policy. Forthcoming, DOI: 10.1515/peps-2016-0034.

Buhaug, Halvard. 2015. Climate-Conflict Research: Some Reflections on the Way Forward. WIREs Climate Change 6(3): 269-275

Buhaug, Halvard. 2010. Climate Not to Blame for African Civil Wars. Proceedings of the National Academy of Sciences 107(38): 16477-16482.

Buhaug, Halvard, Tor A. Benjaminsen, Espen Sjaastad, and Ole Magnus Theisen. 2015. Climate Variability, Food Production Shocks, and Violent Conflict in Sub-Saharan Africa. Environmental Research Letters 10(12): 269-275.

Buhaug, H., J. Nordkvelle, T. Bernauer, T. Böhmelt, et al.. 2014. One Effect to Rule Them All? A Comment on Quantifying the Influence of Climate on Human Conflict. Climatic Change 127(3-4): 391-398.

Buhaug, Halvard, Lars-Eric Cederman, and Kristian Skrede Gleditsch. 2014. Square Pegs in Round Holes: Inequalities, Grievances, and Civil War. International Studies Quarterly 58(2): 418-431.

Burke, Marshall, Solomon M. Hsiang, and Edward Miguel. 2015a. Climate and Conflict. Annual Review of Economics 7(1): 577-617

Burke, Marshall, Solomon M. Hsiang, and Edward Miguel. 2015b. Global Non-linear Effects of Temperature on Economic Production. Nature 527: 235-239. 
Burke, Marshall, Edward Miguel, Shanker Satyanath, John Dykema, and David Lobell. 2009. Warming Increases the Risk of Civil War in Africa. Proceedings of the National Academy of Sciences 106(49): 20670-20674.

Canetti-Nisim, Daphna, Eran Halperin, Keren Sharvit, and Stevan E. Hobfoll. 2009. A New Stress-Based Model of Political Extremism: Personal Exposure to Terrorism, Psychological Distress, and Exclusionist Political Attitudes. Journal of Conflict Resolution 53(3): 363-389.

Caruso, Paul, Ilaria Petrarca, and Roberto Ricciuti. 2016. Climate Change, Rice Crops, and Violence: Evidence from Indonesia. Journal of Peace Research 53(1): 66-83.

Catani, Claudia, Nadja Jacob, Elisabeth Schauer, Mahendran Kohila, and Frank Neuner. 2008. Family Violence, War, and Natural Disasters: A Study of the Effect of Extreme Stress on Children's Mental Health in Sri Lanka. BMC Psychiatry 8(33): 1-10.

Cederman, Lars-Erik, Kristian Skrede Gleditsch, and Halvard Buhaug. 2013. Inequality, Grievances, and Civil War. Cambridge: Cambridge University Press.

Cederman, Lars-Erik, Nils Weidmann, and Kristian Skrede Gleditsch. 2011. Horizontal Inequalities and Ethonationalist Civil War: A Global Comparison. American Political Science Review 105(3): 478-495.

Cederman, Lars-Erik, Andreas Wimmer, and Brian Min. 2010. Why Do Ethnic Groups Rebel? New Data and Analysis. World Politics 62(1): 87-119.

Chaney, Eric. 2013. Revolt on the Nile: Economic Shocks, Religion, and Political Power. Econometrica 81: 2033-2053.

Clarke, Kevin. 2009. Return of the Phantom Menace: Omitted Variable Bias in Political Research. Conflict Management and Peace Science 26(1): 46-66.

Clarke, Kevin. 2005. The Phantom Menace: Omitted Variable Bias in Econometric Research. Conflict Management and Peace Science 22(4): 341-352. 
CAN. 2007. National Security and the Threat of Climate Change. CAN Corporation, Alexandria, VA.

Collier, Paul. 2000. Policy for Post-Conflict Societies: Reducing the Risks of Renewed Conflict. Oxford University: Typescript.

Dancygier, Rafaela M. 2010. Immigration and Conflict in Europe. New York: Cambridge University Press.

Davies, James Chowning. 1962. Toward a Theory of Revolution. American Sociological Review 27(1): 5-19.

Dell, Melissa, Benjamin Jones, and Benjamin Olken. 2014. What Do We Learn from the Weather? The New Climate-Economy Literature. Journal of Economic Literature 52(3): 740-798.

Dell, Melissa, Benjamin Jones, and Benjamin Olken. 2012. Temperature Shocks and Economic Growth: Evidence from the Last Half Century. American Economic Journal: Macroeconomics 4(3): 66-95.

Dessai, Suraje, W. Neil Adger, Mike Hulme, John Turnpenny, Jonathan Köhler, Rachel Warren. 2004. Defining and Experiencing Dangerous Climate Change: An Editorial Essay. Climatic Change 64: 11-25.

Doherty, Thomas J., and Susan Clayton. 2011. The Psychological Impacts of Global Climate Change. American Psychologist 66(4): 265-276.

Dennig, Francis, Mark B. Budolfson, Marc Fleurbaey, Asher Siebert, and Robert H. Socolow. 2015. Inequality, Climate Impacts on the Future Poor, and Carbon Prices. Proceedings of the National Academy of Sciences 112(52): 15827-15832.

Drury, John, Rupert Brow, Roberto González, and Daniel Miranda. 2016. Emergent social identity and observing social support predict social support provided by survivors in a disaster: Solidarity in the 2010 Chile earthquake. European Journal of Social Psychology 46(2): 209-223. 
Drury, John, Chris Cocking, and Steve Reicher. 2009. Everyone for Themselves? A Comparative Study of Crowd Solidarity among Emergency Survivors. British Journal of Social Psychology 48(3): 487-506.

Eisler, Richard M., Jay R. Skidmore, and Clay H. Ward. 1988. Masculine Gender-Role Stress: Predictor of Anger, Anxiety, and Health-Risk Behaviors. Journal of Personality Assessment 52(1): 133-141.

Ember, Carol R., and Melvin Ember. 1994. War, Socialization, and Interpersonal Violence. Journal of Conflict Resolution 38(4): 620-646.

EM-DAT: The OFDA/CRED International Disaster Database. Université Catholique de Louvain, Brussels (Belgium). Available online at: http://www.emdat.be.

Esposito, John L., and John O. Voll. 1996. Islam and Democracy. New York: Oxford University.

Fearon, James, and David Laitin. 2011. Sons of the Soil, Migrants, and Civil War. World Development 39(2): 199-211.

Ferrer-i-Carbonell, Ada, and John Gowdy. 2007. Environmental Degradation and Happiness. Ecological Economics 60(3): 509-516.

Fjelde, Hanne, and Nina von Uexkull. 2012. Climate Triggers: Rainfall Anomalies, Vulnerability and Communal Conflict in Sub-Saharan Africa. Political Geography 31: 444-453.

Foresight Migration and Global Environmental Change. 2011 Final Project Report. The Government Office for Science, London. Available online at: http://www.bis.gov.uk/foresight/ migration.

Gartzke, Erik, and Tobias Böhmelt. 2015. Climate and Conflict: Whence the Weather? Peace Economics, Peace Science and Public Policy 21(4): 445-451.

Garbarino, James. 1995. Raising Children in a Socially Toxic Environment. San Francisco, CA: Jossey-Bass. 
Gelman, Andrew, and Jennifer Hill. 2007. Data Analysis Using Regression and Multilevel/Hierarchical Models. Cambridge: Cambridge University Press.

Gemenne, Francois. 2011. Why the Numbers Don't Add Up: A Review of Estimates and Predictions of People Displaced by Environmental Changes. Global Environmental Change 21(S1): S41-S49.

Ghimire Ramesh, Susana Ferreira, and Jeffrey Dorfman. 2015. Flood-Induced Displacement and Civil Conflict. World Development 66: 614-628.

Gleditsch, Nils Peter, Ragnhild Nordås, and Idean Salehyan. 2007. Climate Change and Conflict: The Migration Link. Coping with Crisis Working Paper Series. New York: International Peace Academy.

Goldstone, Jack A. 2002. Population and Security. How Demographic Change Can Lead to Violent Conflict. Journal of International Affairs 56(1): 3-21.

Goldstone, Jack A. 2001. Environmental Conflict: An Anthology. Boulder, CO: Westview Press.

Gurr, Ted R. 1970. Why Men Rebel. Princeton, NJ: Princeton University Press.

Haer, Roos, and Tobias Böhmelt. 2016. Child Soldiers as Time Bombs? Adolescents' Participation in Rebel Groups and the Recurrence of Armed Conflict. European Journal of International Relations 22(2): 408-436.

Hall, Jonathan. 2016. Are Migrants More Extreme Than Locals After War? Evidence from a Simultaneous Survey of Migrants in Sweden and Locals in Bosnia. Journal of Conflict Resolution 60(1): 89-117.

Hecker, Tobias, Katharin Hermenau, Anna Maedl, Harald Hinkel, Maggie Schauer, and Thomas Elbert. 2013. Does Perpetrating Violence Damage Mental Health? Differences between Forcibly Recruited and Voluntary Combatants in DR Congo. Journal of Traumatic Stress 26(1): 142-148. 
Hobfoll, Steven E., Daphna Canetti-Nisim, and Robert J. Johnson. 2006. Exposure to Terrorism, Stress-Related Mental Health Symptoms, and Defensive Coping among Jews and Arabs in Israel. Journal of Consulting and Clinical Psychology 74(2): 207-218.

Holt, Stephanie, Helen Buckley, and Sadhbh Whelan. 2008. The Impact of Exposure to Domestic Violence on Children and Young People: A Review of the Literature. Child Abuse \& Neglect 32(8): 797-810.

Homer-Dixon, Thomas F. 1999. Environment, Scarcity, Violence. Princeton, NJ: Princeton University Press.

Hsiang, Solomon M., Marshall Burke, and Edward Miguel. 2013. Quantifying the Influence of Climate on Human Conflict. Science 341(6151): 1235367.

Hsiang, Solomon M., Kyle C. Meng, and Mark A Cane. 2011. Civil Conflicts are Associated with the Global Climate. Nature 476: 438-441.

Hunter, Lori M., Jessie K. Luna, and Rachel M. Norton. 2015. Environmental Dimensions of Migration. Annual Review of Sociology 41(6): 1-21.

IPCC Fifth Assessment Report (AR5). 2014. Climate Change 2014: Synthesis Report. Available online at: http://www.ipcc.ch/pdf/assessment-report/ar5/syr/SYR_ AR5_LONGERREPORT.pdf.

Jencson, Linda. 2001. Disastrous Rites: Liminality and Communitas in a Flood Crisis. Anthropology and Humanism 26(1): 46-58.

Kahl, Colin H. 2006. States, Scarcity, and Civil Strife in the Developing World. Princeton, NJ: Princeton University Press.

Kawachi, Ichiro, and Lisa Berkman. 2001. Social Ties and Mental Health. Journal of Urban Health 78(3): 458-467.

Kelley, Colin P., Shahrzad Mohtadi, Mark A. Cane, Richard Seager, and Yochanan kushnir. 2015. Climate Change in the Fertile Crescent and Implications of the Recent Syrian Drought. Proceedings of the National Academy of Sciences 112(11): 3241-3246. 
Koubi, Vally, Gabriele Spilker, Lena Schaffer, and Tobias Böhmelt. 2016. The Role of Environmental Perceptions in Migration Decision-making: Evidence from both Migrants and Nonmigrants in Five Developing Countries. Population \& Environment 38(2): 134163.

Koubi, Vally, Sebastian Stoll, and Gabriele Spilker. 2016. Perceptions of Environmental Change and Migration Decisions. Climatic Change 138(3): 439-451.

Koubi, Vally, Thomas Bernauer, Anna Kalbhenn, and Gabriele Spilker. 2012. Climate Variability, Economic Growth, and Conflict. Journal of Peace Research 49(1): 113-127.

Kreft, Sönke, and David Eckstein. 2014. Global Climate Risk Index 2014. Who Suffers Most from Extreme Weather Events? Weather-Related Loss Events in 2012 and 1993 to 2012. Briefing Paper, Germanwatch. Available online at: https://germanwatch.org/en/ download/8551.pdf.

Laczko, Frank, and Christine Aghazarm (eds.). 2009. Migration, Environment, and Climate Change: Assessing the Evidence. Geneva: International Organization for Migration.

Lilleør, Helene Bie, and Katleen Van den Broeck. 2011. Economic Drivers of Migration and Climate Change in LDCs. Global Environmental Change 21(S1): S70-S81.

Linke, Andrew M., John O’Loughlin, J. Terrence McCabe, Jaroslav Tir, and Frank D.W. Witmer. 2015. Rainfall Variability and Violence in Rural Kenya: Investigating the Effects of Drought and the Role of Local Institutions with Survey Data. Global Environmental Change 34(1): 35-47.

Linke, Andrew M., Sebastian Schutte, and Halvard Buhaug. 2015. Population Attitudes and the Spread of Political Violence in Sub-Saharan Africa. International Studies Review 17(1): 26-45.

Lischer, Sarah Kenyon. 2008. Security and Displacement in Iraq. International Security 33(2): 95-119. 
Luechinger, Simon, and Paul A. Raschky. 2009. Valuing Flood Disasters Using the Life Satisfaction Approach. Journal of Public Economics 93(3-4): 620-633.

Lyall, Jason, Graeme Blair, and Kosuke Imai. 2013. Explaining Support for Combatants during Wartime: A Survey Experiment in Afghanistan. American Political Science Review 107(4): 679-705.

Lyons, Terrence. 2007. Conflict-generated Diasporas and Transnational Politics in Ethiopia. Conflict, Security, and Development 7(4): 529-549.

Maddison, David, and Katrin Rehdanz. 2011. The Impact of Climate on Life-Satisfaction. Ecological Economics 70(12): 2437-2445.

Marshall Monty G., Keith Jaggers, and Ted Robert Gurr. 2013. Polity IV Project: Political Regime Characteristics and Transitions, 1800-2013. Available online at: http://www.systemicpeace.org/ inscrdata.html.

Massey, Douglas S. 1990. Social Structure, Household Strategies, and the Cumulative Causation of Migration. Population Index 56(1): 3-26.

Massey, Douglas S., William Axinn, and Dirgha J. Ghimire. 2010 Environmental Change and Out-Migration: Evidence from Nepal. Population and Environment 32(1): 109-136.

Maystadt, Jean-Francois, and Olivier Ecker. 2014. Extreme Weather and Civil War in Somalia: Does Drought Fuel Conflict in Somalia through Livestock Price Shocks? American Journal of Agricultural Economics 96: 1157-1182.

Mirowsky, John, and Catherine E. Ross. 2003. Social Causes of Psychological Distress. Hawthorne, New York: Aldine de Gruyter, $2^{\text {nd }}$ edition.

Moser, Caroline O., and David Rodgers. 2005. Change, Violence, and Insecurity in NonConflict Situations. Working Paper 245. London: Overseas Development Institute.

Mortreux, Colette, and Jon Barnett. 2009. Climate Change, Migration, and Adaptation in Funafuti, Tuvalu. Global Environmental Change 19(1): 105-112. 
Myers, Norman. 2002 Environmental Refugees: A Growing Phenomenon of the 21 st Century. Philosophical Transactions of the Royal Society 357(1420): 609-613.

Myers, Norman. 1993. Ultimate Security: The Environmental Basis of Political Stability. New York: Norton.

Myers, Norman. 2002 Environmental Refugees: A Growing Phenomenon of the 21 st Century. Philosophical Transactions of the Royal Society 357(1420): 609-613.

ND-GAIN (Notre Dame Global Adaptation Index). 2013. Climate Change Adaptation Program. University of Notre Dame Environmental Change Initiative. Available online at: http://index.gain.org/ranking.

Nel, Philip, and Marjolein Righarts. 2008. Natural Disasters and the Risk of Violent Civil Conflict. International Studies Quarterly 52(1): 159-185.

Norwegian Refugee Council (IDMC). 2015. Global Estimates 2015: People Displaced by Disasters. Available online at: https://www.worldhumanitariansummit.org/node/505018.

O’Loughlin, John, Frank D.W. Witmer, Andrew M. Linke, Arlene Laing, Andrew Gettelman, and Jimy Dudhia. 2012. Climate Variability and Conflict Risk in East Africa, 1990-2009. Proceedings of the National Academy of Sciences 109: 18344-1349.

Oyefusi, Aderoju. 2008. Oil and the Probability of Rebel Participation among Youths in the Niger Delta. Journal of Peace Research 45(4): 539-555.

Piazza, James A. 2007. Draining the Swamp: Democracy Promotion, State Failure, and Terrorism in 19 Middle Eastern Countries. Studies in Conflict \& Terrorism 30(6): 521-539. Piguet, Etienne. 2010. Linking Climate Change, Environmental Degradation, and Migration: A Methodological Overview. Climate Change 1(4): 517-524.

Prediger, Sebastian, Bjorn Vollan, and Benedikt Herrmann. 2014. Resource Scarcity and Antisocial Behavior. Journal of Public Economics 119: 1-9.

Rabe-Hesketh, Sophia, and Anders Skrondal. 2009. Multilevel and Longitudinal Modeling Using Stata. College Station, TX: Stata Press. 
Raleigh, Clionadh, Lisa Jordan, and Idean Salehyan. 2008. Assessing the Impact of Climate Change on Migration and Conflict. Paper Prepared for the Social Dimensions of Climate Change, World Bank.

Reardon, Thomas, and J. Edward Taylor. 1996. Agroclimatic Shock, Income Inequality, and Poverty. Evidence from Burkina Faso. World Development 24(5): 901-914.

Renaud, Fabrice G., Olivia Dun, Coco Warner, and J. Bogardi. 2011. A Decision Framework for Environmentally Induced Migration. International Migration 49(1): e3-e29.

Reuveny, Rafael. 2007. Climate Change-Induced Migration and Violent Conflict. Political Geography 26(6): 656-673.

Rodriguez, Havidan, Joseph Trainor, and Enrico L Quarantelli. 2006. Rising to the Challenges of a Catastrophe: The Emergent and Pro-social Behavior Following Hurricane Katrina. Annals of the American Academy of Political and Social Science 604(1): 82-101.

Rummel, Rudolph Joseph. 1976. Perceiving and Behaving. In Understanding Conflict and War: The Conflict Helix. Beverly Hills, CA: Sage Publications.

Salehyan, Idean. 2014. Climate Change and Conflict: Making Sense of Disparate Findings. Political Geography 43(1): 1-5.

Salehyan, Idean. 2008. From Climate Change to Conflict? No Consensus Yet. Journal of Peace Research 45(3): 315-326.

Salehyan, Idean. 2007. Refugees and the Study of Civil War. Civil Wars 9(2): 127-141.

Salehyan, Idean, and Kristian Skrede Gleditsch. 2006. Refugee Flows and the Spread of Civil War. International Organization 60(2): 335-366.

Sandler, Todd. 1992. Collective Action: Theory and Applications. Ann Arbor, MI: University of Michigan Press.

Schaffer, Lena Maria and Gabriele Spilker. 2016 Adding Another Level: Individual Responses to Globalization and Government Welfare Policies. Political Science Research and Methods 4 (2): 399-426 
Schleussner, Carl-Friedrich, Jonathan F. Donges, Reik V. Donner and Hans Joachim Schellnhuber. 2016. Armed-conflict risks enhanced by climate-related disasters in ethnically fractionalized countries. Proceedings of the National Academy of Sciences 113(33): 9216-9221.

Sedikides, Constantine, Tim Wildschut, Clay Routledge, Jamie Arndt, and Xinyue Zhou. 2009. Buffering Acculturative Stress and Facilitating Cultural Adaptation: Nostalgia as a Psychological Resource. In: Robert S.Wyer, Chi-yue Chiu, and Ying-yi Hong (ed.): Understanding Culture: Theory, Research and Application. New York: Psychology Press, pp. 361-378.

Sen, Amartya. 2011. A Peace and Democratic Society. Cambridge: Open Book Publisher.

Shuval, Judith. 2001. Migration, Health, and Stress. In: William C. Cockerham (ed), The Blackwell Companion to Medical Sociology. Malden, MA: Blackwell Publishers, pp. 126143.

Smith, Todd Graham. 2014. Feeding Unrest: Disentangling the Causal Relationship between Food Price Shocks and Sociopolitical Conflict in Urban Africa. Journal of Peace Research 51(6): 679-695.

Stern, Jessica. 2010. How to deradicalize Islamist extremists: Mind over martyr. Foreign Affairs 89(1): 95-108.

Suhrke, Astri. 1997. Environmental Degradation, Migration, and the Potential for Violent Conflict. In: Nils Petter Gleditsch et al. (ed.): Conflict and the Environment, Dordrecht: Kluwer Academic Publishers, 255-272.

Sullivan, John L., George E. Marcus, Stanley Feldman, and James E. Piereson. 1981. The Sources of Political Tolerance: A Multivariate Analysis. American Political Science Review 75(1): 92-106. 
Taft, Casey T., Suzannah K. Creech, and Lorig Kachadourian. 2012. Assessment and Treatment of Posttraumatic Anger and Aggression: A Review. Journal of Rehabilitation Research and Development 49(5): 777-788.

Theisen, Ole Magnus, Nils Petter Gleditsch, and Halvard Buhaug. 2013. Is Climate Change a Driver of Armed Conflict? Climatic Change 117:613-625.

Theisen, Ole Magnus, Helge Holtermann, and Halvard Buhaug. 2011. Climate Wars? Assessing the Claim that Drought Breeds Conflict. International Security 36(1): 79-106.

Tol, Richard S J. 2009. The Economic Effects of Climate Change. Journal of Economic Perspectives 23(2): 29-51.

Urdal, Henrik. 2006. A Clash of Generations? Youth Bulges and Political Violence. International Studies Quarterly 50(3): 607-630.

Vinck, Patrick, Phuong N. Pham, Eric Stover, and Harvey M. Weinstein. 2007. Exposure to War Crimes and Implications for Peace Building in Northern Uganda. Journal of the American Medical Association 298(3): 543-554.

Vogt, Manuel, Nils-Christian Bormann, Seraina Rüegger, Lars-Erik Cederman, Philipp Hunziker, and Luc Girardin. 2015. Integrating Data on Ethnicity, Geography, and Conflict: The Ethnic Power Relations Dataset Family. Journal of Conflict Resolution 59(7): 13271342.

Von Uexkull, Nina, Mihai Coicu, Hanne Fjelde, and Halvard Buhaug. 2016. Civil Conflict Sensitivity to Growing Season Drought. Proceedings of the National Academy of Sciences, DOI: 10.1073/pnas.1607542113.

Warner, Coco. 2011. Environmental Change and Migration: Methodological Considerations from Ground-Breaking Global Survey. Population and Environment 33(1): 3-27.

Warraich, Haider, Anita KM Zaidi, and Kavita Patel. 2011. Floods in Pakistan: A Public Health Crisis. Bulletin of the World Health Organization 89(3): 236-237

World Bank. 2014. Climate Risk and Adaptation Country Profiles. Available online at: 
http://sdwebx.worldbank.org/climateportal/countryprofile/home.cfm

Zolberg, Aristide, Astri Suhrke, and Sergio Aguayo. 1989. Escape from Violence: Conflict and the Refugee Crisis in the Developing World. Oxford: Oxford University Press. 